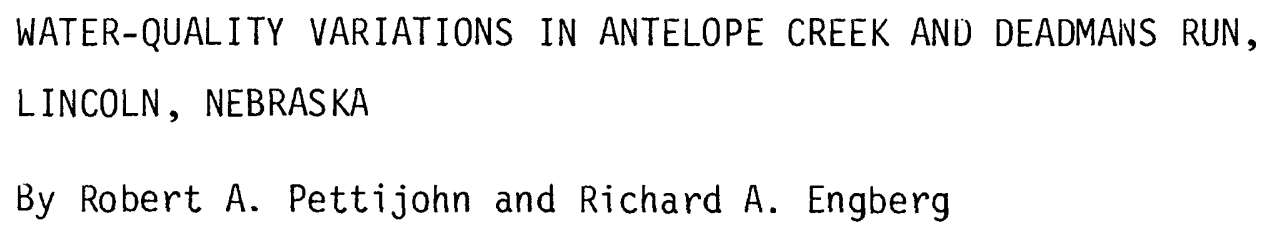

U.S. GEOLOGICAL SURVEY

Water-Resources Investigations Report 85-4153

Prepared in cooperation with the LOWER PLATTE SOUTH NATURAL RESOURCES DISTRICT

$$
\text { Lincoln, Nebraska }
$$

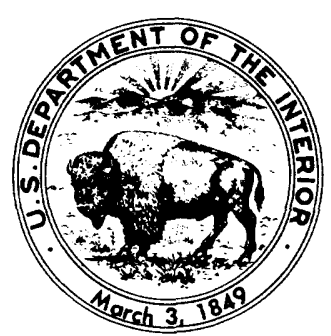




\author{
UNITED STATES DEPARTMENT OF THE INTERIOR \\ DONALD PAUL HODEL, Secretary \\ GEOLOGICAL SURVEY \\ Dallas L. Peck, Director
}

For additional information

write to:

District Chief

U.S. Geological Survey

406 Federal Building

100 Centennial Mall, North

Lincoln, NE 68508
Copies of this report can be purchased from:

Open-File Services Section U.S. Geological Survey Box 25425, Federal Center Denver, C0 80225

Telephone: (303) 234-5888 


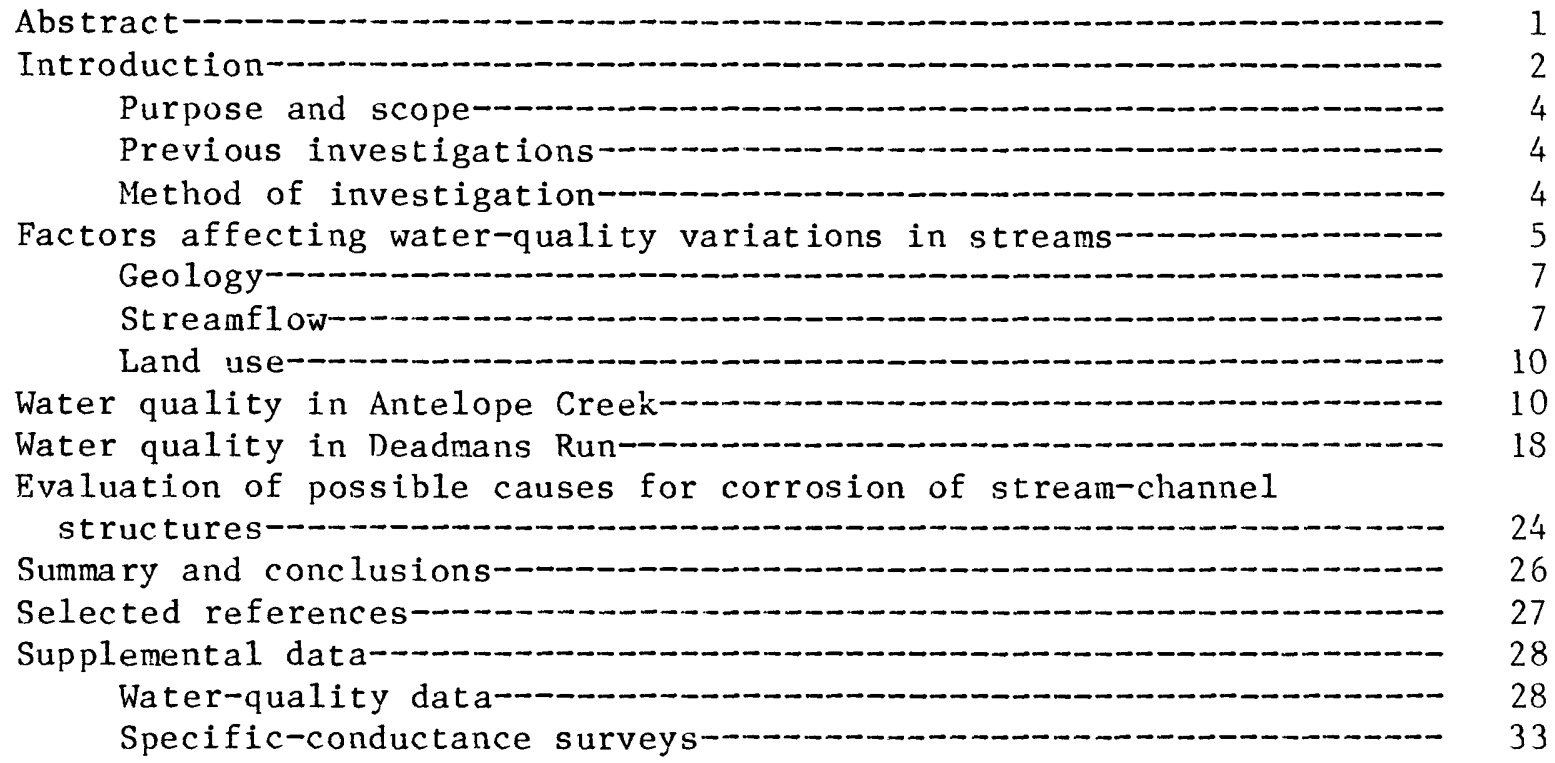

ILLUSTRATIONS

Page

Figure 1. Map showing location of study area-

2.-12. Graphs showing:

2. Measured water discharge at three sampling sites on Antelope Creek, December 1, 1982, to June 9, 1983---

3. Measured water discharge at two sampling sites on Deadmans Run, December 1, 1982, to June 9, 1983-----

4. Specific-conductance profile for entire reach of Antelope Creek, December 1, 1982-

5. Specific-conductance profile for reach from 27 th Street to mouth of Antelope Creek, May 9, 10, 1983--

6. Specific conductance at three sampling sites on Antelope Creek, December 1, 1982, to June 9, 1983---

7. Sodium and chloride concentrations at three sampling sites on Antelope Creek, December 1, 1982 to June 9, 1983-

8. Calcium and bicarbonate concentrations at three sampling sites on Antelope Creek, December 1, 1982 to June 9, 1983-

9. Specific-conductance profile for entire reach of Deadmans Run, December 1, 1982

10. Specific conductance at two sampling sites on Deadmans Run, December 1, 1982, to June 9, 1983

11. Sodium and chloride concentrations at two sampling sites on Deadmans Run, December 1, 1982, to June 9, $1983-\cdots$

12. Calcium and bicarbonate concentrations at two sampling sites on Deadmans Run, December 1, 1982, to June 9, 1983 
Table 1. Date of sample collection, type of sample collection, and hydrologic and climatic conditions at the time of sample collection--

2. Water-quality data from three sites on Antelope Creek and two sites on Deadmans Run, December 1982 through June 1983-

3. Specific-conductance survey of Antelope Creek main channel from Holmes Lake outlet to Fairgrounds bridge west of Bob Devaney Sports Center and principal tributaries or outfalls, December 1, 1982

4. Specific-conductance survey of water from Antelope Creek
main channel and from drains into Antelope Creek tunne main channel and from drains into Antelope Creek tunnel
and seeps into cement-lined channel, May 9, 10, 1983---

5. Specific-conductance survey of Deadmans Run main channel from Wedgewood Lake outlet to U.S. Highway 6 bridge and principal tributaries or outfalls, December 1, 1982----

Multiply inch-pound unit

foot

cubic foot per second $\left(\mathrm{ft}^{3} / \mathrm{s}\right)$

mile

square mile
$\underline{B y}$

0.3048

0.028

1.609

2.59
To obtain SI units

meter

cubic meter per second kilometer

square kilometer 


\title{
WATER-QUALITY VARIATIONS IN ANTELOPE CREEK AND DEADMANS RUN, LINCOLN, NEBRASKA
}

By Robert A. Pettijohn and Richard A. Engberg

\begin{abstract}
Water-quality variations in Antelope Creek and Deadmans Run, two small streams that drain about 60 percent of the area of Lincoln, Nebraska, were studied from December 1982 through June 1983. Eleven sets of samples were collected from each of five sites, three on Antelope Creek and two on Deadmans Run. Specific-conductance surveys were made on December 1, 1982, on both streams, and on May 9-10, 1983, on Antelope Creek. The effects on stream quality of runoff from short-duration storms of storm-sewer effluent and of saline ground-water seepage were assessed. Possible reasons for deterioration of streambank-stabilization structures were determined.

Specific conductance increases greatly in the reach of Antelope Creek from 27 th Street to Court street during low-flow conditions. During a low-flow survey on December 1, 1982, specific conductance, in microsiemens per centimeter at $25^{\circ}$ Celsius, increased from 974 at 27 th street to 8,700 at Court street. This increase is related to seepage into the stream channel of saline water from the underlying Dakota Sandstone. This seepage masks the effect of industrial effluent that enters the stream in the same reach. During high-flow conditions, specific-conductance values are less than at times of low flow. An exception is after winter storms when runoff from salted streets is conveyed into the stream by storm sewers. Sodium and chloride concentrations in water sampled on January 6,1983 , from both the $52 \mathrm{~d}$ and 27 th street sites were from 5 to 10 times greater than those measured for any other water samples collected during either low or high flows.
\end{abstract}

Specific-conductance values increased an average of only 47 percent from the 66 th Street site to the U.S. Highway 6 site on Deadmans Run. Ground-water seepage entering Deadmans Run apparently is not as mineralized as that entering the downstream reaches of Antelope Creek.

Concentrations of dissolved oxygen in both streams often equal or exceed 100 percent saturation, a situation favorable to corrosion of metal. In contrast, $\mathrm{pH}$ values in both streams favor corrosion control.

Three types of metal corrosion are: underwater, underground, or stray current. Stray-current corrosion may occur when current flows between two dissimilar metals. The zinc-coated wire of the channe1stabilization structures may serve as the anode and material within the streambanks may serve as the cathode. Electrochemical dissolution of the zinc coating as a result of stray current may be a possible cause of the channe1-structure deterioration in both streams. 


\section{INTRODUCTION}

About 60 percent of the 60-square-mile area of Lincoln, Nebraska, a city of about 172,000 population, lies within the drainage basins of two small streams--Antelope Creek and Deadmans Run (fig. 1). Included in these basins are a part of downtown Lincoln, the two largest shopping centers in the city, and about 50 percent of the city's industrial area.

Few data have been available concerning the quality of water in these streams, especially during or after rainstorms or during the winter after snowstorms when the streams receive runoff from streets on which salt has been used for snow removal. Recognizing the need for such information as an aid in considering future channel improvements or in regulating further development, the Lower Platte South Natural Resources District, the management and planning agency that has been responsible for channel improvements in both streams, signed a cooperative agreement with the U.S. Geological Survey for a short-term, storm- and runoff-oriented evaluation of the quality of water in both Antelope Creek and Deadmans Run.

The natural quality of water in both streams probably has been altered by man's activity. Flood plains of both streams are highly developed, and 73 known storm sewers and industrial drains discharge into the streams. In addition, small, man-made, flood-control reservoirs upstream near the eastern edge of the city on both streams regulate much of the surface water flowing through the respective reaches. Downstream from Holmes Lake on Antelope Creek and Wedgewood Lake on Deadmans Run, channels of both streams have been straightened in certain parts of their reaches. Stream banks have been stabilized for the most part by the installation of limestone-filled, galvanized-steel cages (gabions) in a stairstepped fashion on each side of the channels. However, in the downstream reach of Antelope Creek, water flows through a cement-lined tunnel, which is 0.7 mile in length, underlying a business and residential area just east of the central business district of Lincoln and continues through an open, cement channel nearly to its mouth. The stream banks have been seeded with dense ground cover in the areas of channel straightening and gabion installation to help prevent erosion. Some of the steel cages, which have been in place for 10 years or more, have deteriorated badly, allowing their load of rocks to spill into the stream channel.

The quality of water in the streams also may be affected by natural hydrogeologic factors, especially in the downstream reaches of Antelope Creek. Saline water from the underlying Dakota Formation of Cretaceous age seeps into the stream. The originating source of the saline water has not been determined. It may move into the Dakota Formation from underlying older deposits but could have been trapped in the formation at the time of deposition. 


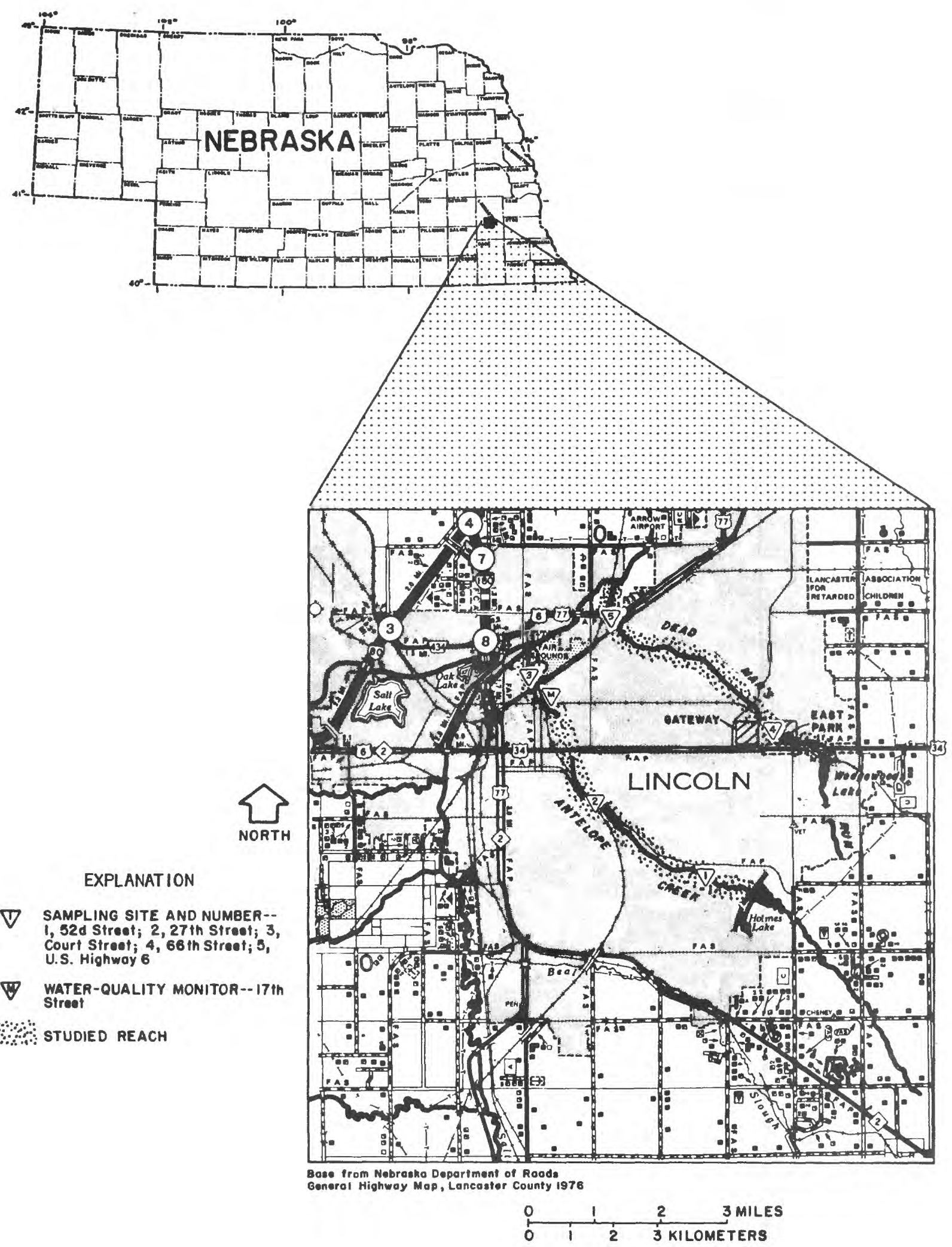

Figure 1.--Location of the study area. 
The purpose of this study was to assess and evaluate the short-term quality of water in Antelope Creek and Deadmans Run for a variety of flow conditions. The objectives of the study were:

1. Determine the magnitude of the change in water quality due to short-term rainstorms and snowmelt and identify the stream reaches where water-quality changes occur.

2. Determine the effect of locally generated effluents or discharges on the quality of water in the streams and determine the stream reaches that are affected.

3. Determine the magnitude of the change in water quality due to seepage of saline ground water and identify stream reaches where water-quality changes occur.

4. Evaluate possible causes for deterioration of the streambankstabilization structures.

5. Provide collected information and data in a form that can be used by managers and planners in preparing future development plans in the basins.

\section{$\underline{\text { Previous Investigations }}$}

There are no previous investigations specifically to determine the chemical quality of water in Antelope Creek and Deadmans Run. However, an investigation by Kister and Mundorff (1963) describes the sedimentation and chemical quality of water in the Salt Creek basin, which includes the smaller basins of Antelope Creek and Deadmans Run. In addition, a statistical summary of the quality of water in Antelope Creek at Court Street, based on quarterly samples collected during 1971-77, was made by Engberg (1980).

The hydrogeology of northern Lancaster County, which includes the two small basins, is described by Holly (1980). Hydrogeology appears to have a significant effect on stream water quality in Lancaster County. A similar report by Goodenkauf (1978) was prepared for southern Lancaster County.

\section{Method of Investigation}

This investigation primarily was the collection of streamflow data and water-quality samples for on-site and laboratory analysis. The data collected were interpreted relative to factors that affect chemical quality in the present environment.

A small network of sampling sites was established--three on Antelope Creek at 52d, 27th, and Court Streets, and two on Deadmans Run at $66 \mathrm{th}$ Street and at the U.S. Highway 6 crossing (fig. 1). Water samples for 
principal constituents and nutrients were collected monthly. Four additional sets of measurements and samples were obtained after rainstorms or during snowmelt runoff. Water discharge, $\mathrm{pH}$ (hydrogen-ion concentration), specific conductance, dissolved oxygen, and water and air temperatures were measured at the time of sample collection. Analyses were performed by the U.S. Geological Survey laboratory in Arvada, Colorado. The results from all laboratory analyses are in table 2 in the Supplemental Data section at the back of the report.

Specific conductance and $\mathrm{pH}$ were measured at several locations on each stream at the beginning of the study on December 1, 1982. Water discharge, specific conductance, $\mathrm{pH}$, and seepage to Antelope Creek along a reach from 27th Strect to Court Street were measured on May 9-10, 1983 . Data collected during both of these synoptic surveys also are presented in table 2 .

A four-channel, continuous-recording, water-quality monitor was installed in a shelter on Antelope Creek at 17 th Street on the University of Nebraska Campus. At this location, Antelope Creek flows through an open, cement-lined channel. The monitor, which was attached to a stripchart recorder, was equipped with a chamber containing specificconductance, $\mathrm{pH}$, dissolved-oxygen, and water-temperature probes. The monitor was operational from late December 1982 until May 1, 1983, when the probes were destroyed by high water. A continuous-stage recorder operated in connection with the monitor.

The dates on which samples were collected at the three sites on Antelope Creek and at the two sites on Deadmans Run are listed in table 1 . Also contained in the table is a description of the hydrologic or climatic conditions or both at the time of sample collection.

\section{FACTORS AFFECTING WATER-QUALITY VARIATIONS IN STREAMS}

Precipitation absorbs small quantities of gases and particulate matter from the atmosphere. Some precipitation flows over the Earth's surface as runoff. This runoff dissolves some soluble material from soils and transports sediment to streams. Another part of precipitation seeps through permeable surfaces of the Earth dissolving material from soils and rock and is stored underground.

The solution of material by water generally is greater beneath the land surface because water and rocks are in contact with each other for longer periods. Therefore, ground water normally is more roncentrated with solutes than is surface water and can introduce additional minerals by seepage to streams. The composition of soil and rock is important in determining ground-water solute concentration and thus affects water quality. The effects of ground water on stream quality are more noticeable during low flows when ground-water seepage may become the principal component of the streamflow and, thus, have a dominating effect on stream quality. 
Table 1.--Date of sample collection, type of sample collected, and hydrologic and climatic conditions at the time of sample collection

\begin{tabular}{|c|c|c|}
\hline $\begin{array}{l}\text { Date of } \\
\text { collection }\end{array}$ & Sample type & Conditions \\
\hline $12-01-82$ & Monthly & Low flow \\
\hline $01-06-83$ & Monthly; runoff & $\begin{array}{l}\text { Water quality affected by snowmelt run- } \\
\text { off from salted streets. }\end{array}$ \\
\hline $02-10,11-83$ & Monthly & Low flow \\
\hline $02-14-83$ & Runoff & $\begin{array}{l}\text { Samples collected after a rainstorm; } \\
\text { water quality affected by rainfall } \\
\text { runoff. }\end{array}$ \\
\hline $03-05-83$ & $--\mathrm{d} 0--+--\infty$ & Do. \\
\hline $03-14-83$ & Monthly & Low flow \\
\hline $03-26-83$ & Runoff & $\begin{array}{l}\text { Samples collected during and after a } \\
\text { rainstorm; water quality affected by } \\
\text { rainfall runoff. }\end{array}$ \\
\hline $04-07,08-83$ & Monthly & Low flow \\
\hline $04-13,14-83$ & Runoff & $\begin{array}{l}\text { Samples collected during runoff after a } \\
\text { major spring snowstorm. No street } \\
\text { salting. Greatest water discharge at } \\
\text { most sites during period of study. }\end{array}$ \\
\hline $05-09-83$ & Monthly & Low flow \\
\hline $06-09-83$ & -- do-- - - - - - & Do. \\
\hline
\end{tabular}


Geologic deposits exposed at land surface in the basins of Antelope Creek and Deadmans Run are alluvial, eolian, and glacial deposits of Quaternary age, and sandstone and shale of Cretaceous age. The sandstone and shale of the Dakota Formation of Cretaceous age immediately underlie the Quaternary deposits in most of the two basins.

The alluvial, eolian, and glacial deposits yield small quantities of water to wells. The dissolved-solids concentrations in water from these deposits usually are less than $1,000 \mathrm{mg} / \mathrm{L}$ (milligrams per liter). Calcium is the principal cation and bicarbonate is the principal anion. Where the dissolved-solids concentrations are greater, the increase is due to greater concentrations of sodium and chloride. This indicates that water from the Dakota Formation has infiltrated into the unconsolidated deposits.

The rocks of the Dakota Formation vary from permeable sandstone to almost impermeable shale. The Dakota Formation in the study area yields water containing large concentrations of dissolved solids. For example, data for water from a well in Lincoln indicates that chloride increased with depth from $748 \mathrm{mg} / \mathrm{L}$ at 55 feet to $6,200 \mathrm{mg} / \mathrm{L}$ at 151 feet (Kister and Mundorff, 1963).

\section{Streamflow}

Reservoirs are located at the upstream end of the studied reaches of both Antelope Creek and Deadmans Run. Except during rainfall or snowmelt, streamflow is regulated at low flow by releases from the reservoirs. Considerable variations in dissolved solids prevail; that is, large concentrations prevail at low flow (concentrating effect); whereas, small concentrations prevail at high flow (dilution effect).

From Holmes Lake in southeast Lincoln, Antelope Creek flows northwest through the eastern edge of downtown Lincoln to discharge into Salt Creek, a distance of about 5 miles. This reach of the stream drains an area of about 12 square miles. The maximum and minimum measured discharges at the downstream site during the period of study were 44.0 and $1.0 \mathrm{ft}^{3} / \mathrm{s}$ (cubic feet per second) ( $\mathrm{fig} .2$ ). The median discharge was $5.8 \mathrm{ft}^{3} / \mathrm{s}$. Instantaneous discharges during the study may have been considerably greater than the maximum measured discharge at certain times.

From Wedgewood Lake in east Lincoln, Deadmans Run flows northwest through the northeast quarter of Lincoln and discharges into Salt Creek, a distance of about 5 miles. This reach of the stream drains an area of about 8 square miles. The maximum and minimum discharges measured near the mouth during the study were 63.0 and $1.6 \mathrm{ft}^{3} / \mathrm{s}$ ( $\mathrm{fig} .3$ ). The median discharge was $2.9 \mathrm{ft}^{3} / \mathrm{s}$. Because measurements were made randomly, instantaneous discharges at times during the study may have been considerably greater than the maximum measured discharge. 


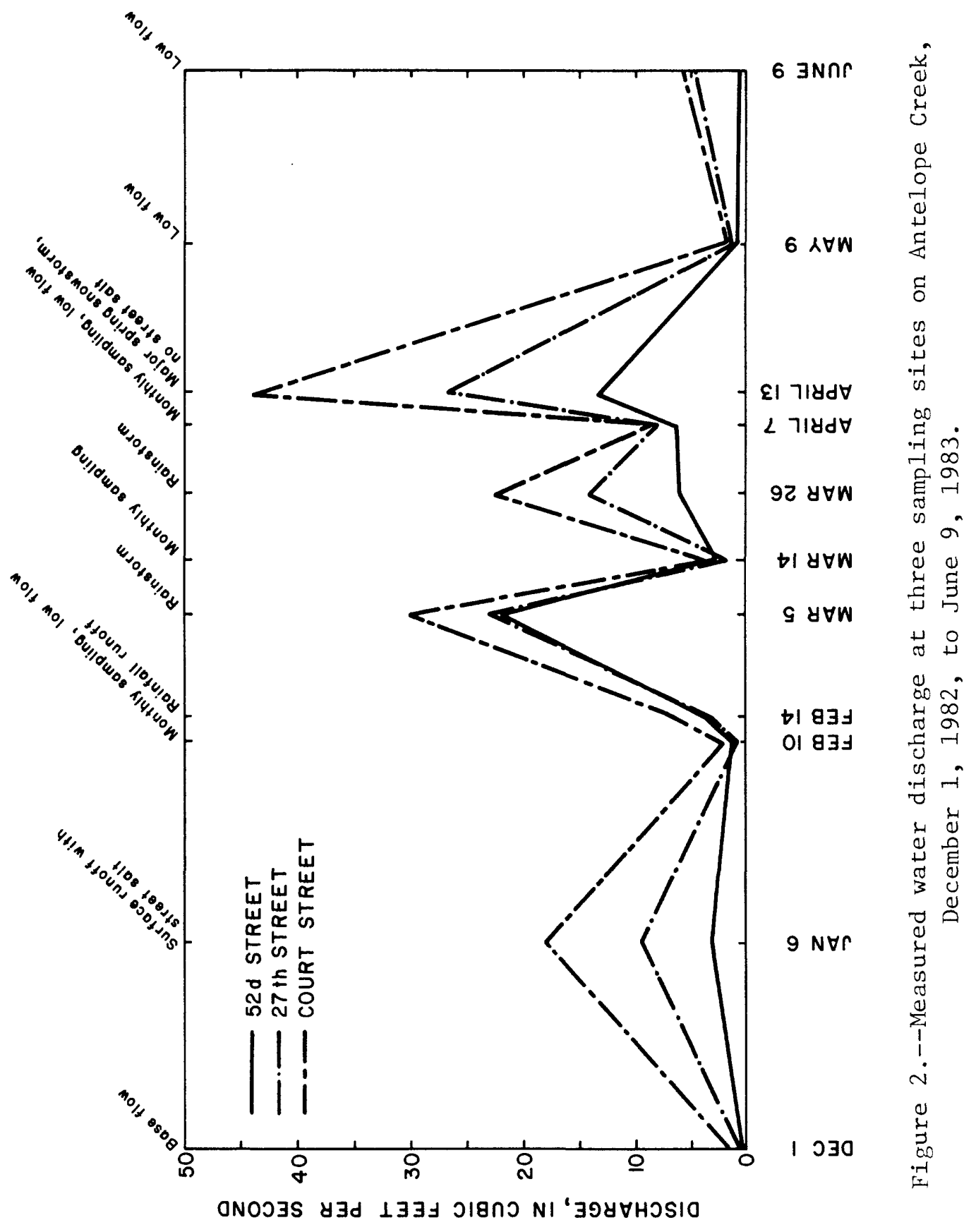




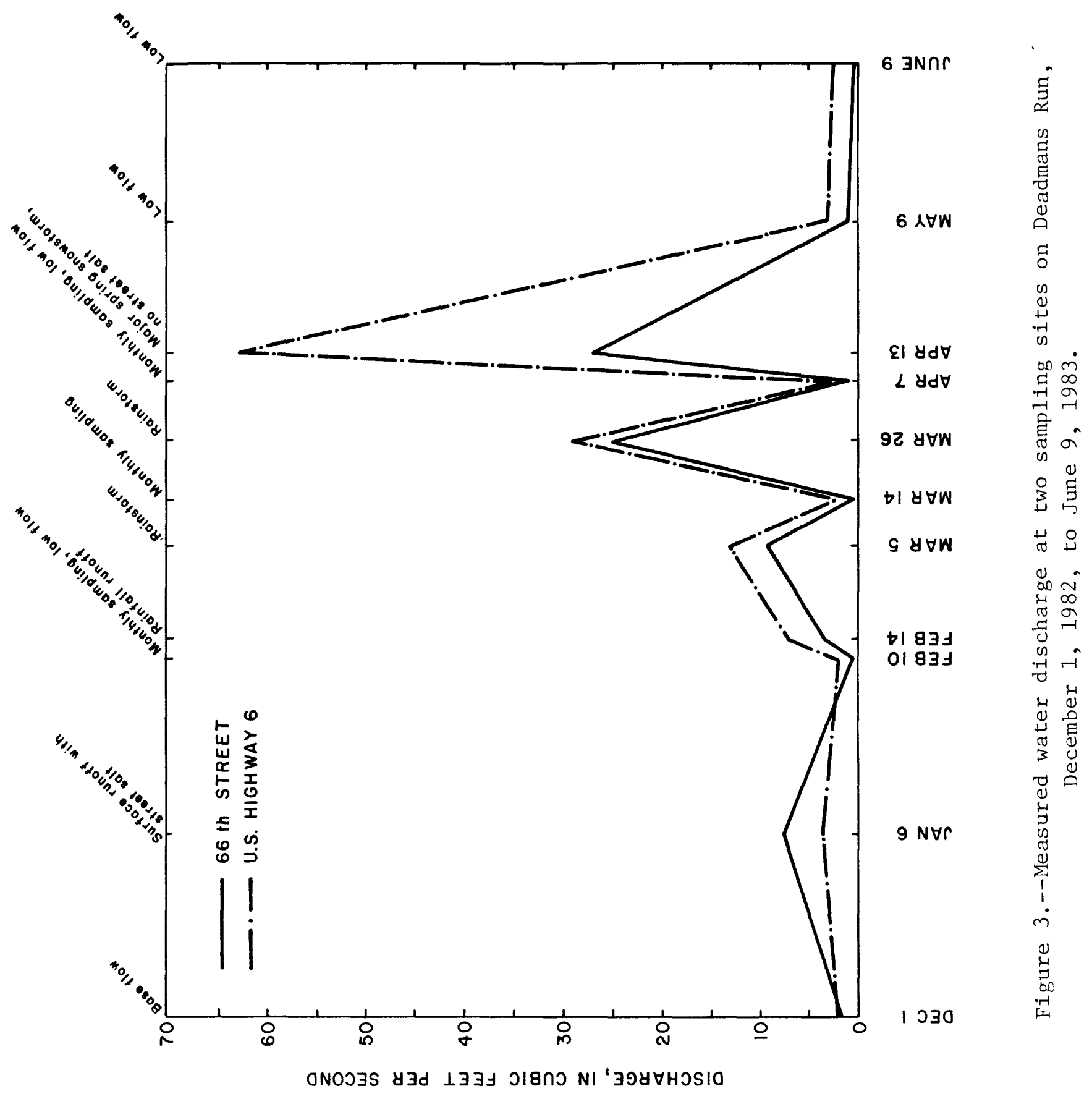


Land Use

Land use in the two small basins principally is urban, with industrial and commercial areas located near the mouths of the two streams. A small amount of farmland still remains in a few areas.

Urban areas consist primarily of single-family homes, but multifamily housing is increasing. In addition, there are four institutions of higher learning in the two basins.

Products produced by the industries include such items as boxes and containers, electrical and electronic equipment, foodstuffs, machinery and machine tools, pharmaceuticals, rubber products, motorcycles, and commercial vehicles. Commercial establishments line many of the main arterial streets. The effluent from most industries and commercial establishments is discharged into the city's sewer system; at times, some effluent may flow directly into the downstream reaches of both creeks.

Because the developed area is sewered, the source of discharge to the streams primarily is surface runoff, which may transport street salt during the winter and fertilizer in the spring and summer. Surface runoff from farmland may contain sediment if rainfall is intense; but because acreage is small and most rainstorms are short, sediment concentration in the two small streams generally is not a serious problem.

\section{WATER OUALITY IN ANTELOPE CREEK}

Specific conductance, which can be used to estimate dissolved-solids concentration, remained fairly constant in the reach from the Holmes Lake outlet to $27 \mathrm{th}$ Street (referred to as the upstream reach in this report) during a survey consisting of specific-conductance measurements made at close intervals along the reach of Antelope Creek at low-flow conditions on December 1, 1982. However, the survey showed that specific conductance increased greatly in the reach from 27 th Street to Court Street (referred to as the downstream reach in this report) (fig. 4). This increase is attributed to the seepage of saline water from underlying bedrock directly into the stream. The location and effect of the saline ground-water seepage was more clearly defined during a similar survey May 9-10, 1983, again at low flow along the downstream reach of Antelope Creek (fig. 5). Results of the specific-conductance surveys are presented in tables 3 and 4 in the Supplemental Data section. Similarly, specific-conductance measurements made during low flow at the three designated sampling sites during the study also indicated large specific-conductance values in the downstream reach of the stream (fig. 6). Conversely, when specificconductance measurements were made during high flows such as during or after rainstorms or snowmelt, the values were nearly the same at all three sites.

During low flow, streamflow at the 52d street sampling site virtually was the same as that from the reservoir outlet 0.4 mile upstream. Between the $52 \mathrm{~d}$ Street and $27 \mathrm{th}$ Street sampling sites, only a very small increase in streamflow occurred. The small increase in streamflow probably may be 


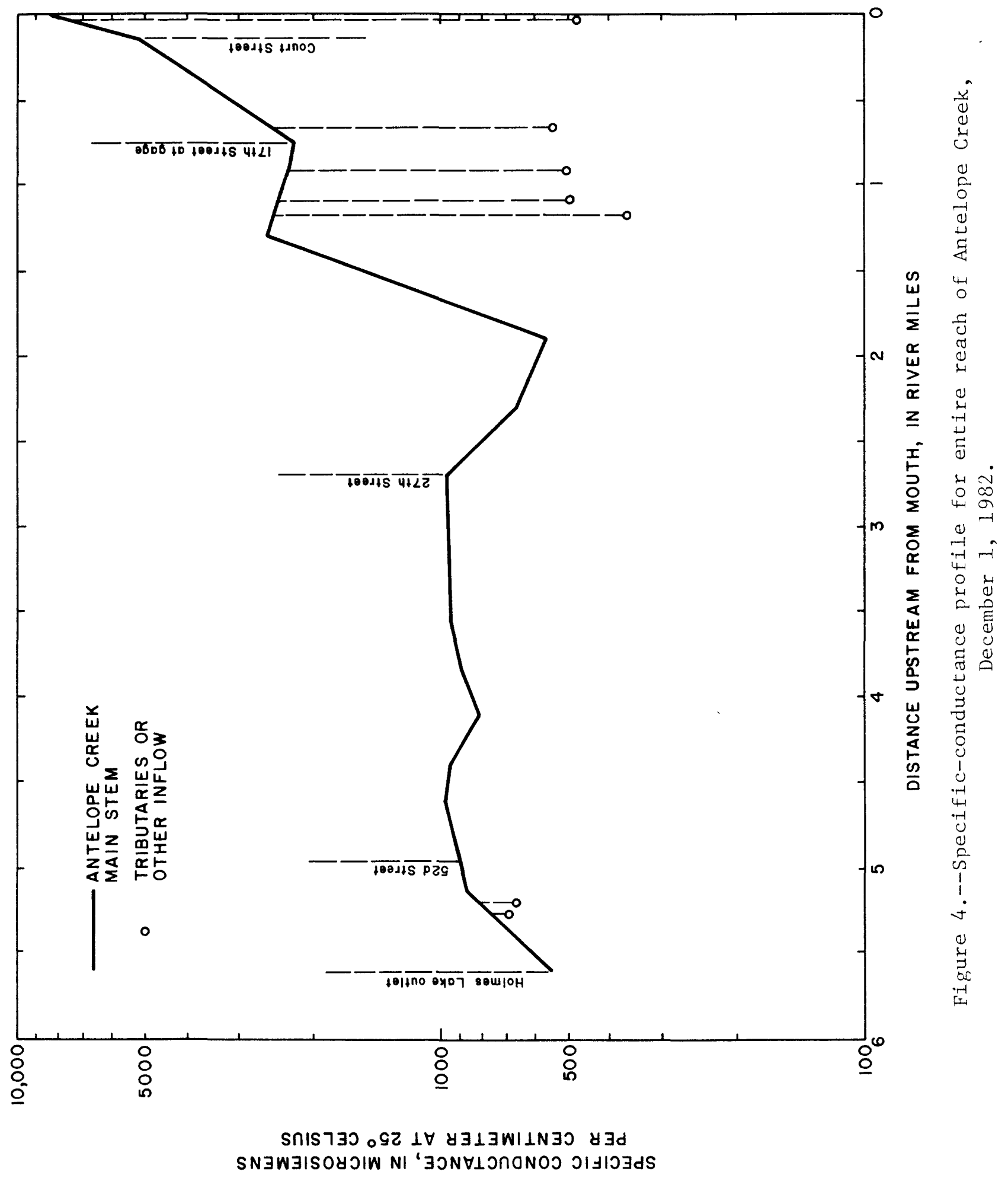




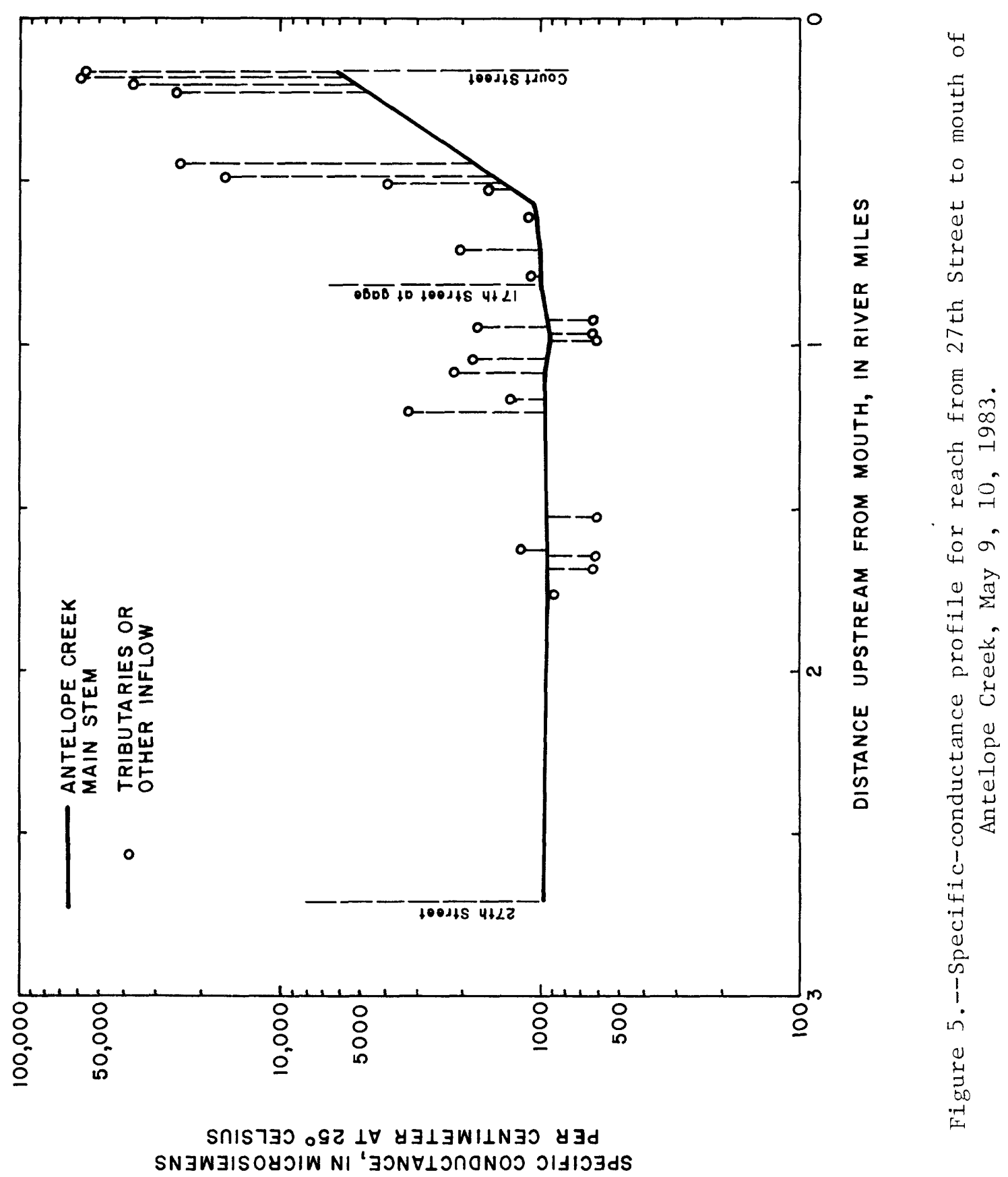




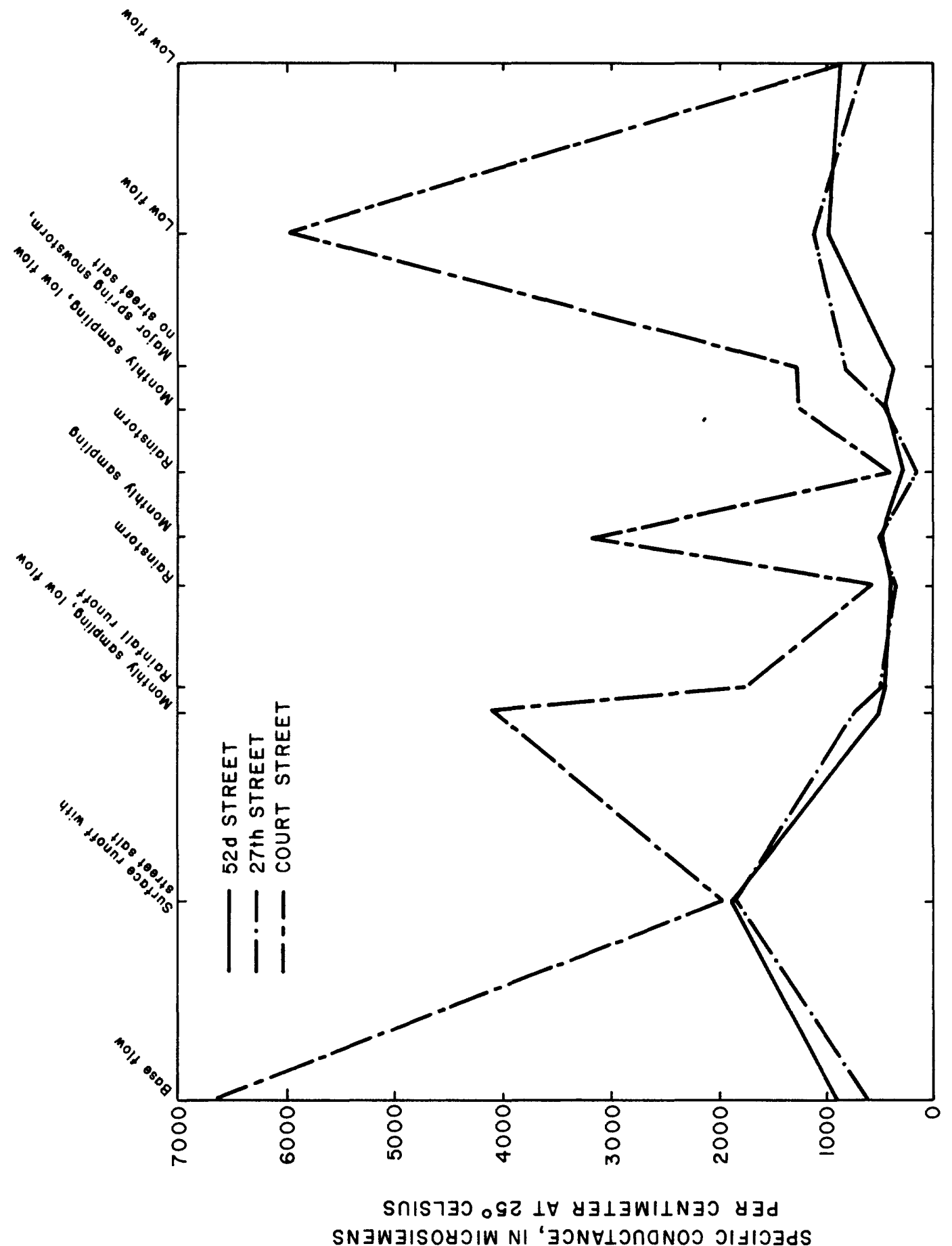

6 ヨNกก

ع| ᄀاله

L רוلעd

$92 \forall \forall W$

$\forall \mid \forall \forall w$

G $\forall \forall w$

이

이 83y

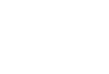

$9 N \forall r$ 
attributed to a small quantity of ground-water seepage to the stream channe1. Likewise, the quality of water at the 27 th Street site was very similar to the quality of water at the $52 \mathrm{~d}$ Street site. No industrial effluent enters this reach of the stream.

During high flow, streamflow at the 27 th Street site increases by as much as 100 percent compared to that at the $52 \mathrm{~d}$ Street site. Direct runoff of precipitation or snowmelt and storm-sewer effluent account for the increase. The quality of water at both sites is almost identical during high flow. Specific-conductance values were less than those measured at low flow for water samples collected during or after snowstorms or rainstorms on February 14, March 3, and April 13, 1983, when city streets were not salted. These specific-conductance values were a result of dilution from the less mineralized overland runoff and runoff conveyed by storm sewers. However, after a snowstorm in which runoff from salted streets was conveyed into the stream by storm sewers, specific-conductance values measured in samples collected January 6, 1983, were the maximums measured during the study at both the $52 \mathrm{~d}$ and $27 \mathrm{th}$ Street sites. These maximum specific-conductance values resulted from addition of large concentrations of sodium and chloride contained in the salt used on the streets. Sodium and chloride concentrations were from 5 to 10 times greater than those measured in any other sample collected during either low or high flows (fig. 7). Concentrations of calcium and bicarbonate (the principal cation and anion) in water at both sites, however, were similar to those measured at both sites during low flow (fig. 8).

During low flow, streamflow at the Court Street site is only slightly greater than that at the $27 \mathrm{th}$ Street site. However, based on specificconductance measurements, it is apparent that the quality of water changes greatly between the two sites (fig. 5). Seepage of the previously mentioned saline ground water into a reach about 0.5 mile long just upstream from the Court Street site apparently accounts for the change in quality. For example, on December 1,1982 , sodium concentrations were $40 \mathrm{mg} / \mathrm{L}$ at $27 \mathrm{th}$ Street but increased to $1,300 \mathrm{mg} / \mathrm{L}$ at Court Street. Ch1oride concentrations were $29 \mathrm{mg} / \mathrm{L}$ at $27 \mathrm{th}$ Street but increased to $1,900 \mathrm{mg} / \mathrm{L}$ at Court Street. Calciun and bicarbonate (converted from alkalinity) at $27 \mathrm{th}$ Street increased from 60 to $100 \mathrm{mg} / \mathrm{L}$, and from 240 to $301 \mathrm{mg} / \mathrm{L}$, respectively, within the same reach. Observable effluent from an industrial area enters the stream just upstream from the Court Street site. Effects of this effluent probably are masked by the much more mineralized ground water.

During high flow, streamflow is more than 50 percent greater at the Court street site than at the $27 \mathrm{th}$ Street site. This increased volume of water, which is attributed to direct surface runoff and storm-sewer effluent, apparently minimizes the effect of the saline ground-water seepage on the water quality in the reach. Only relatively small changes in concentrations of calcium, sodium, chloride, or bicarbonate (computed from alkalinity concentrations) occur in the reach. For example, in samples collected on March 26, 1983, after a rainstorm, sodium concentrations increased from $21 \mathrm{mg} / \mathrm{L}$ at $27 \mathrm{th}$ Street to $58 \mathrm{mg} / \mathrm{L}$ at Court Street, and chloride concentrations increased from 29 to $80 \mathrm{mg} / \mathrm{L}$ within the same 


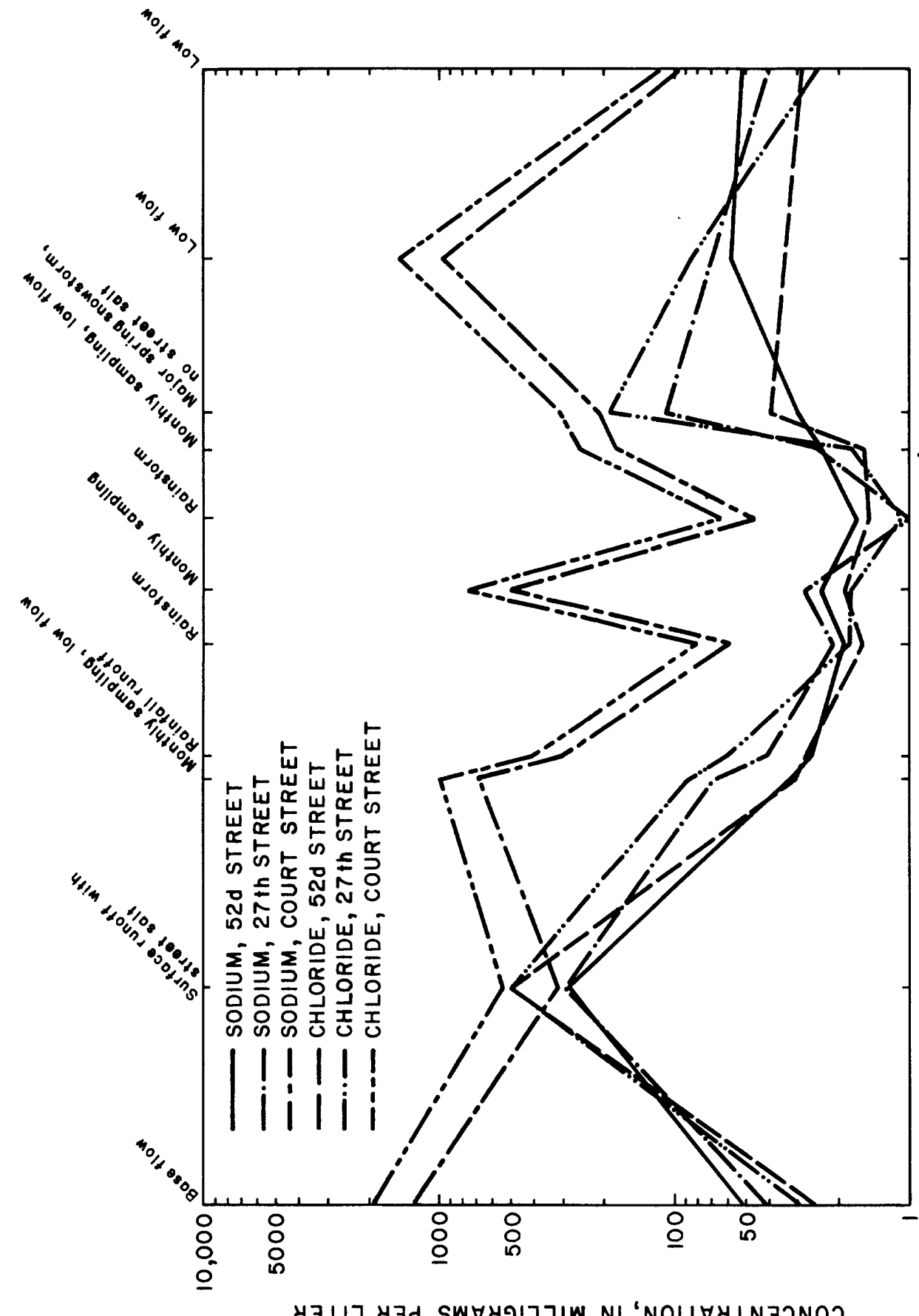

6 3nnR

$6 \wedge \forall W$

ธี

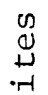

$6 \wedge \forall W$

\&I רוلd

$<$ רI8d

Gट $\forall \forall w$

† $\forall \forall W$

$\mathrm{G} \forall \forall W$

$6183 y$

이 $83 \pm$

$9 N \forall r$

1030

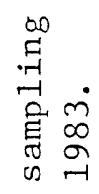

ปี

崩

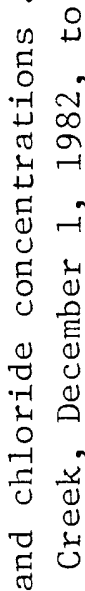

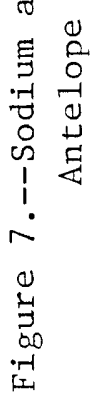

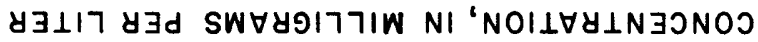




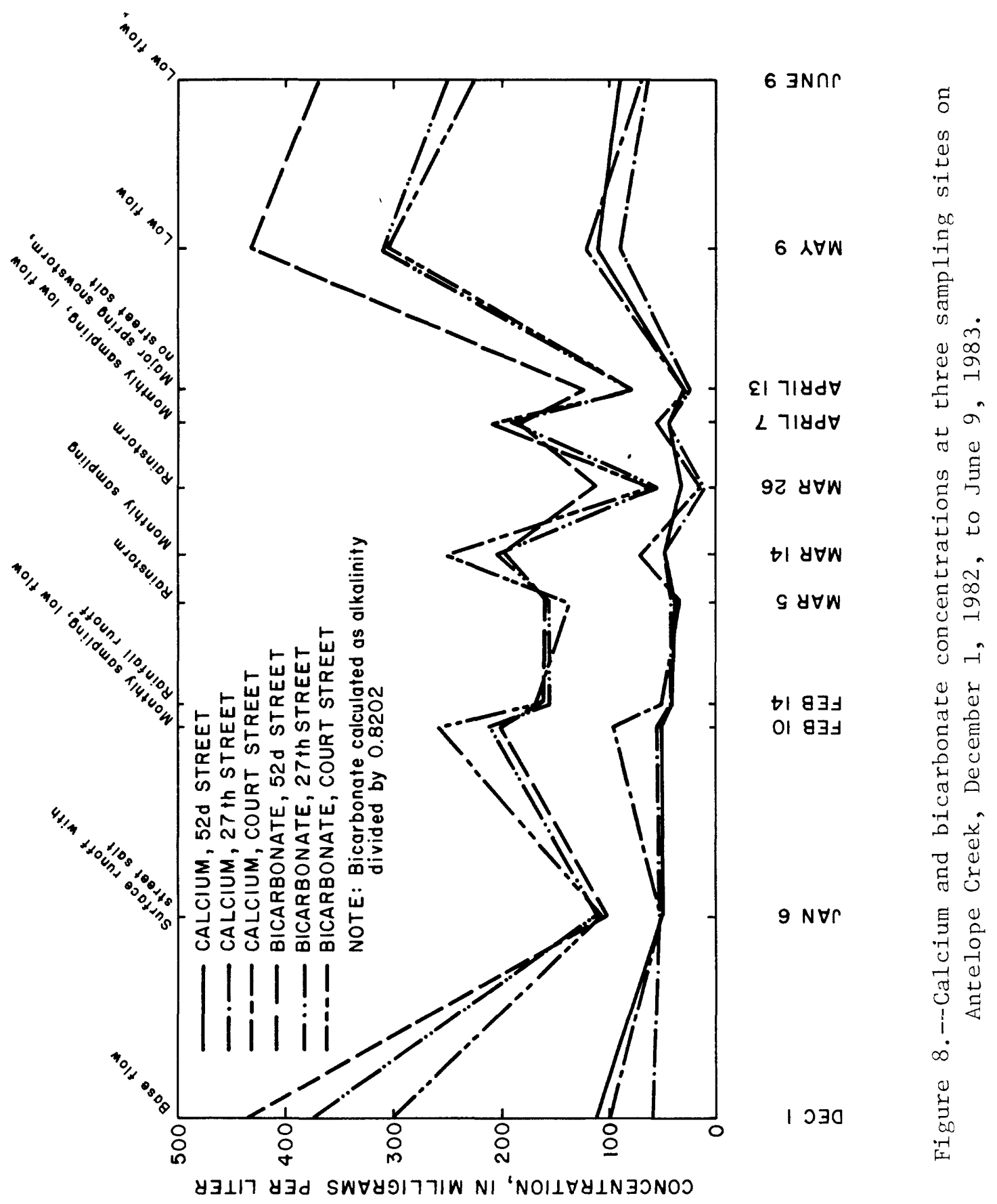


reach. Calcium concentrations decreased from 39 to $35 \mathrm{mg} / \mathrm{t}$ within the reach. Bicarbonate concentrations decreased from $158 \mathrm{mg} / \mathrm{L}$ at $27 \mathrm{th}$ Street to $138 \mathrm{mg} / \mathrm{L}$ at Court Street.

Nitrate-nitrogen concentrations for all samples collected at the three sites on Antelope Creek ranged from 0.34 to $4.2 \mathrm{mg} / \mathrm{L}$; both the minimum and maximum concentrations were in samples from the 27 th street site. Median concentrations for 11 samples from each site were $0.76 \mathrm{mg} / \mathrm{L}$ at $52 \mathrm{~d}$ Street, $0.94 \mathrm{mg} / \mathrm{h}$ at $27 \mathrm{th}$ Street, and $1.5 \mathrm{mg} / \mathrm{L}$ at Court Street. A11 nitrate-nitrogen concentrations were much less than the Federal drinkingwater standard of $10 \mathrm{mg} / \mathrm{L}$ (U.S. Environmental Protection Agency, 1976) for all samples collected at all sites on Antelope Creek. Concentrations of nitrate-nitrogen in the stream may increase slightly during summer months after rainstorms when storm-sewer discharge may contain some fertilizer washed from lawns.

Concentrations of dissolved oxygen usually were almost or slightly greater than 100 percent saturation of oxygen ( $14.6 \mathrm{mg} / \mathrm{L}$ at $0{ }^{\circ} \mathrm{Ce} 1 \mathrm{sius}$ and 760 millimeters of mercury, Sawyer and McCarty, 1967) in water at all sites on Antelope Creek. Dissolved-oxygen concentrations in water are affected principally by water temperature and are affected to a lesser degree by atmospheric pressure and by salinity. Other factors that affect dissolved-oxygen concentrations are photosynthetic activity, turbidity, and oxygen requirements of bacteria associated with degradation of organic wastes. Antelope Creek is very shallow during low flow and on sunny days light may penetrate to the streambed. It is speculated that because photosynthetic activity from algae during the growing season may be substantial during these periods, considerable oxygen may be contributed to the stream and is responsible for the large concentrations of dissolved oxygen. Increased concentrations of dissolved oxygen are known to be significant factors in the increased corrosion of iron and steel, especially in water-distribution systems and steam boilers (Sawyer and McCarty, 1967).

Values of $\mathrm{pH}$, which provide an estimate of the hydrogen-ion concentration in the stream, ranged from 7.2 to 8.6 for all measurements at all three sites on Antelope Creek. The median $\mathrm{pH}$ value for all measurements was 8.0 and the median values at $52 \mathrm{~d}$ Street, 27 th Street, and Court Street sites were $8.1,7.9$, and 8.0, respectively. According to Langlier (as reported in McKee and Wolf, 1963), $\mathrm{pH}$ values from 8.0 to 12.0 favor corrosion control. 
During a survey of the entire reach of Deadmans Run, made during low-flow conditions on December 1, 1982, specific conductance remained fairly constant through the central part of the reach, but was somewhat greater near the upstream end of the reach (fig. 9). A possible explanation for the specific-conductance value of $1,160 \Delta \mathrm{s} / \mathrm{cm}$ (microsiemens per centimeter at $25^{\circ}$ Celsius) in water at 70 th street is that the addition of more mineralized water $(1,260 \Delta \mathrm{S} / \mathrm{cm})$ from the drain at West Rio and Skyway Roads (fig. 9) about 0.5 mile upstream greatly affected the overall specific conductance of the reach. Discharge from the drain may have been responsible for most of the streamflow at 70 th Street, but this cannot be ascertained because water discharges were not measured at the time of the specific-conductance survey. Results of the specific-conductance survey are presented in table 5 in the Supplemental Data section.

Specific-conductance measurements made at 66 th street and U.S. Highway 6 on Deadmans Run (fig. 10) show an average increase of 47 percent from the upstream site to the downstream site for 11 samples collected between December 10, 1982, and June 9, 1983. The greatest increase in specific conductance from the 66 th Street site to the U.S. Highway 6 site occurred on March 14, 1983, during low-flow conditions. Specific conductance was $1,080 \Delta \mathrm{S} / \mathrm{cm}$ at $66 \mathrm{th}$ Street and $2,850 \Delta \mathrm{S} / \mathrm{cm}$ at U.S. Highway 6 . Conversely, during high flow on March 26, 1983, specific conductance was greater at $66 \mathrm{th}$ Street $(540 \Delta \mathrm{S} / \mathrm{cm})$ than at U.S. Highway $6(245 \Delta \mathrm{S} / \mathrm{cm})$.

During low flow, water discharge increased about 320 percent from a mean of $0.73 \mathrm{ft}^{3} / \mathrm{s}$ at the $66 \mathrm{th}$ street site to a mean of $2.33 \mathrm{ft}^{3} / \mathrm{s}$ at the U.S. Highway 6 site. The means are based on six sampling dates--December 1, 1982, February 11, March 14, April 8, May 9, and June 9, 1983. For the same dates, mean specific conductance increased by 74 percent from 1,018 $\Delta \mathrm{S} / \mathrm{cm}$ at 66 th $\mathrm{Street}$ to $1,768 \Delta \mathrm{S} / \mathrm{cm}$ at U.S. Highway 6. In contrast, for medium to high streamflow, water discharge increased 61 percent from a mean of $14.4 \mathrm{ft}^{3} / \mathrm{s}$ at the $66 \mathrm{th}$ street site to a mean of $23.2 \mathrm{ft}^{3} / \mathrm{s}$ at the U.S. Highway 6 site. These means are based on five sampling dates-January 6, February 14, March 5 and 26, and April 14, 1983. For the same dates, mean specific conductance increased 10 percent from $801 \mathrm{~s} / \mathrm{cm}$ at 66 th Street to $879 \Delta \mathrm{S} / \mathrm{cm}$ at U.S. Highway 6 . Seepage of ground water into the channel probably accounts for most of the increase in water discharge and also for the increase in specific conductance at the U.S. Highway 6 site during low-flow conditions. Less mineralized runoff from storms is responsible for the smaller specific-conductance values measured in the stream during medium to high streamflow.

Sodium and chloride concentrations in water samples collected during low flow from the entire studied reach of Deadmans Run ( $f i g .11$ ) were similar to those from the reach of Antelope Creek between $52 \mathrm{~d}$ and 27 th Streets, but were markedly different from those of Antelope Creek between 27 th and Court Streets. Concentrations of both constituents usually were three to four times greater in water at the U.S. Highway 6 site than in water at the 66th Street site collected on the same days. This change probably is the result of seepage of ground water in the reach that is somewhat enriched in sodium and chloride. Although Deadmans Run is not in 


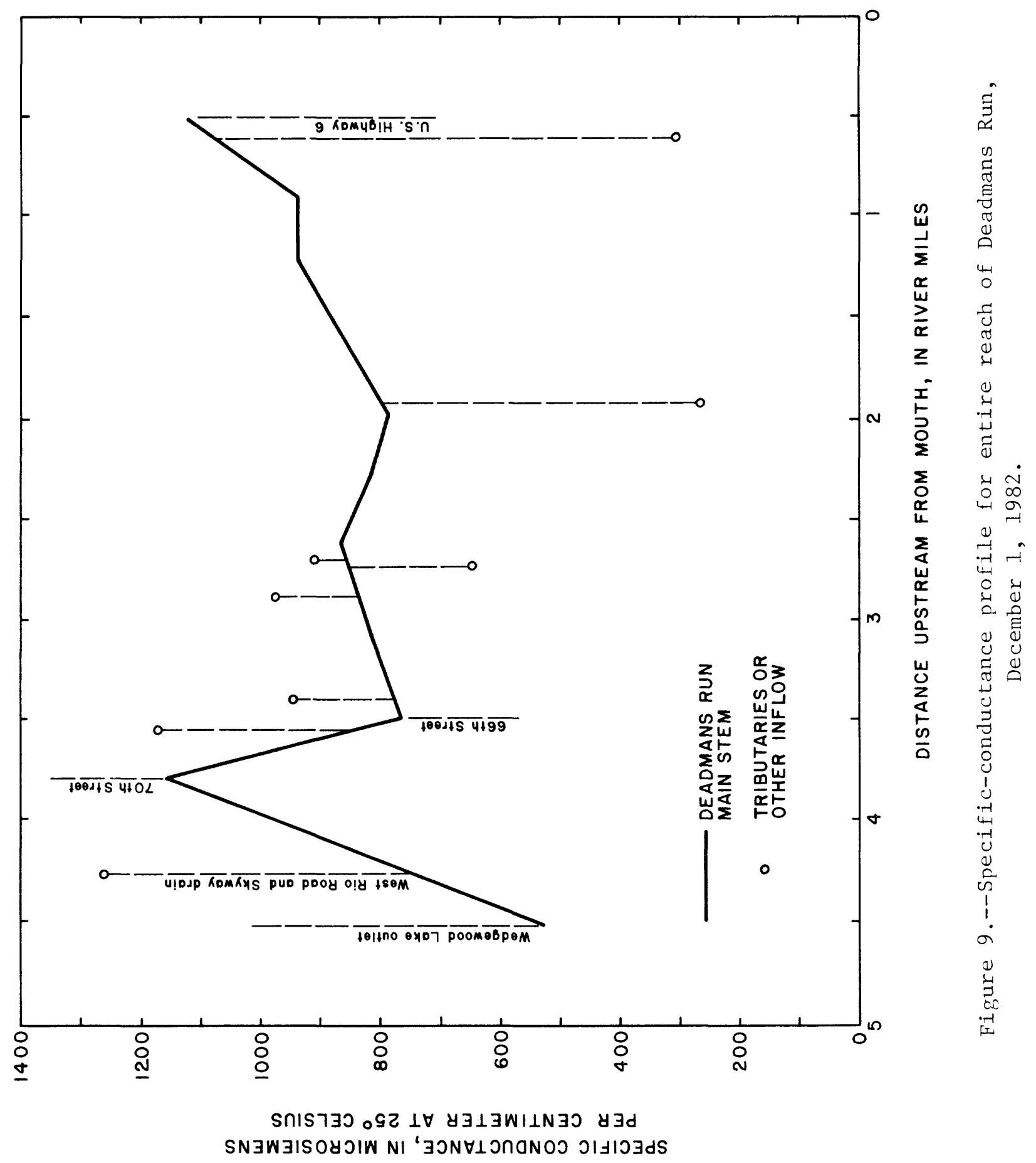




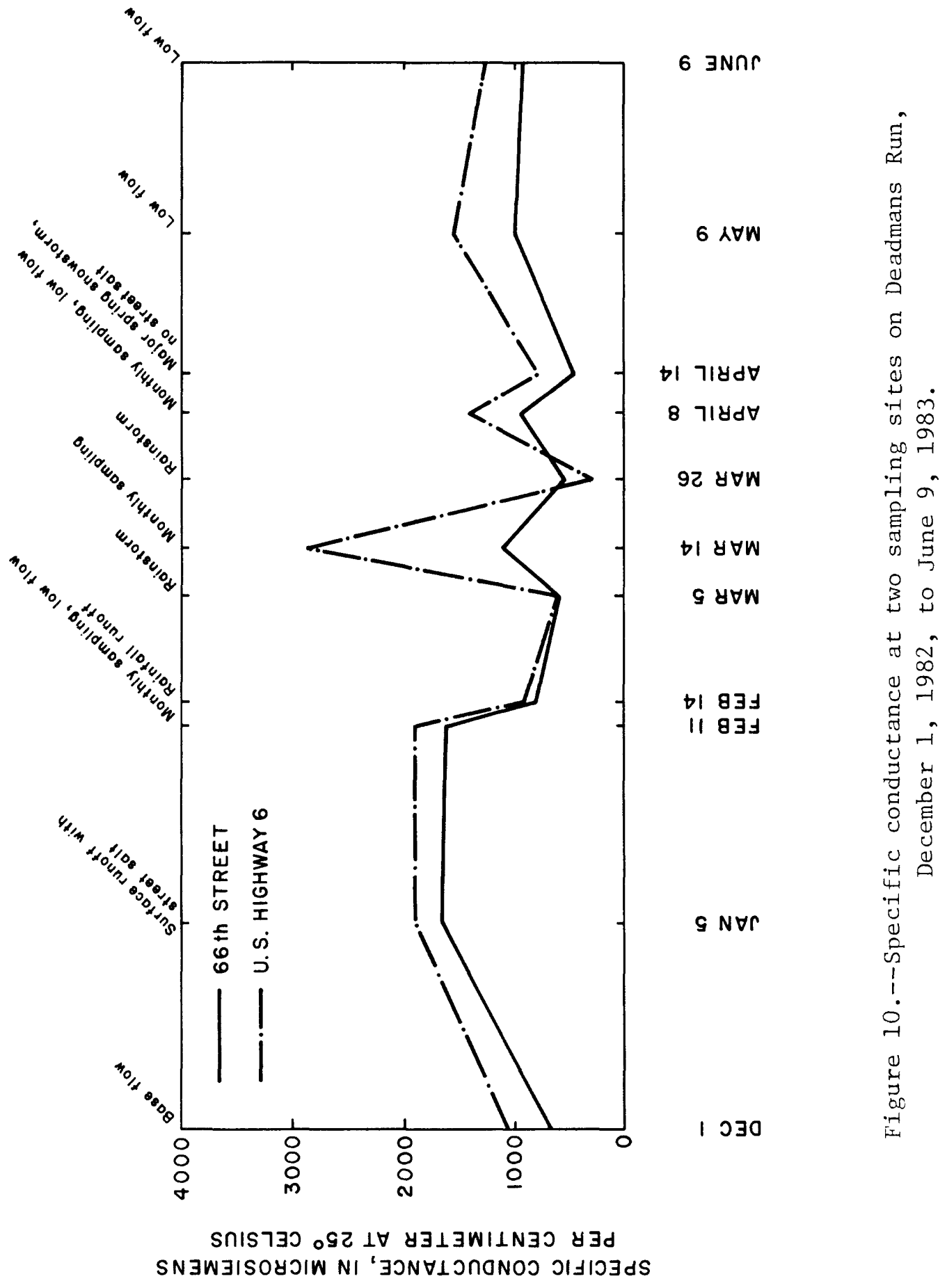




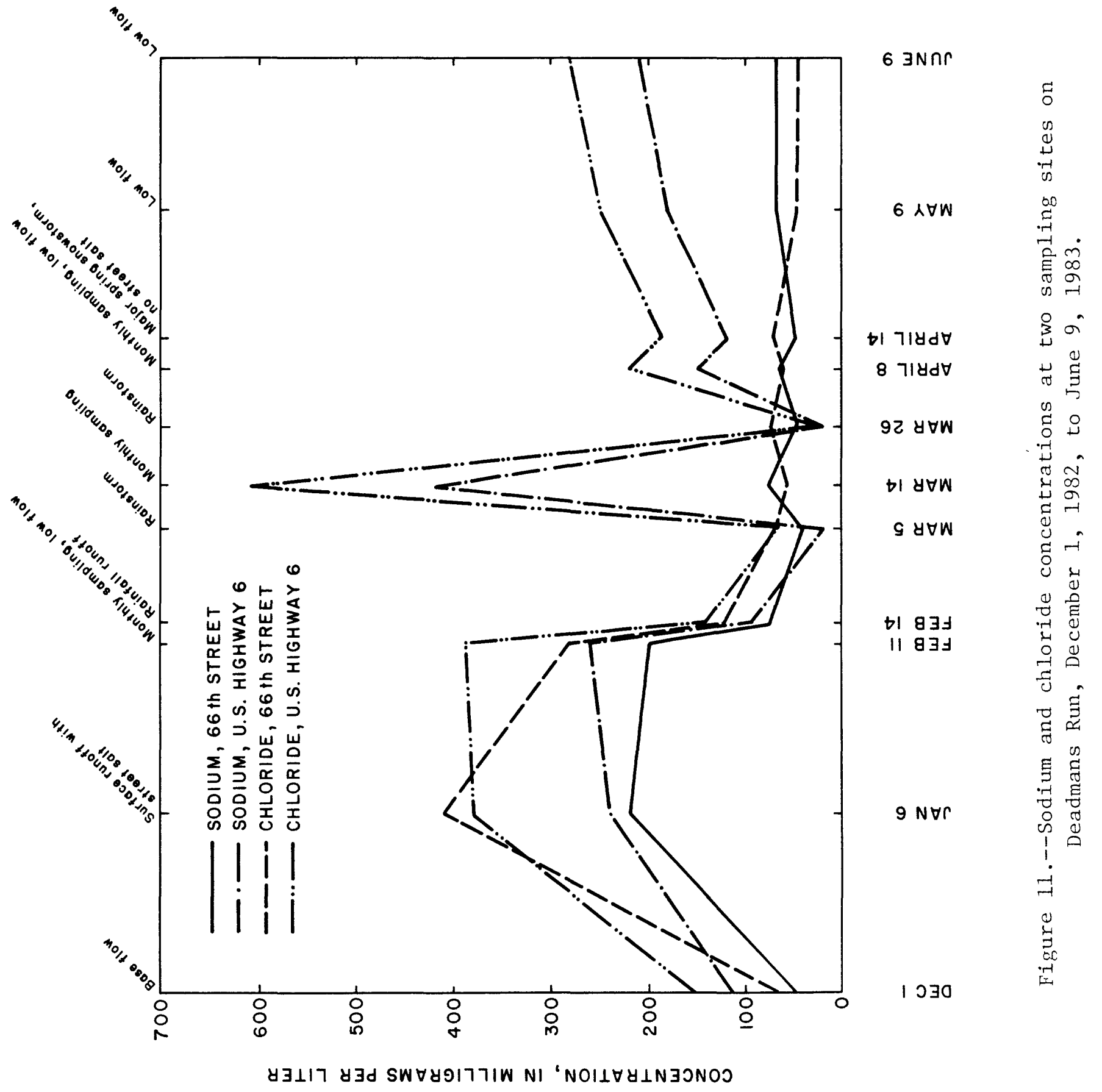


direct hydraulic connection with the saline water derived from the Dakota Formation, which markedly affects the quality of streamflow in the reach of Antelope Creek between $27 \mathrm{th}$ and Court Streets, the saline water probably affects indirectly the quality of streamflow in Deadmans Run. Some upward movement of saline water from the Dakota Formation into the alluvial deposits in the valley of Deadmans Run may occur. Water from the alluvium thus enriched in sodium and chloride may seep into the stream.

During high flows, sodium and chloride concentrations were small and were almost the same in water at the $66 \mathrm{th}$ Street and the U.S. Highway 6 sites. Relatively dilute runoff masks the effect of ground-water seepage on concentrations of these constituents during high flow. Samples collected on January 6, 1983, were an exception. Sodium concentrations were 220 and $240 \mathrm{mg} / \mathrm{t}$ and chloride concentrations were 410 and $380 \mathrm{mg} / \mathrm{L}$ at the $66 \mathrm{th}$ Street and U.S. Highway 6 sites, respectively. These concentrations are the result of runoff from streets that were salted to melt ice and snow from a storm a few days earlier. Similar concentrations of sodium and chloride were measured in samples collected March 5, 1983. These samples were collected during a period of warmer temperatures when melt water from snow and ice piled near the stream in the area of the Gateway and East Park shopping centers probably was responsible for the increased sodium and chloride concentrations.

With the exception of the January 6, 1983, sample, calcium and bicarbonate concentrations (computed from alkalinity values) (fig. 12) had a pattern of variation throughout the study for the sampled reach of Deadmans Run much like that of specific conductance (fig. 10). For the sample collected on January 6, 1983, a time when the streamflow was partly runoff from city streets, the bicarbonate concentration was very small in water at the 66th Street site. No reasonable explanation is available for this single anomalous value.

Nitrate-nitrogen concentrations for all samples collected at both sites on Deadmans Run ranged from $0.20 \mathrm{mg} / \mathrm{L}$ at the $66 \mathrm{th}$ Street site to 2.3 $\mathrm{mg} / \mathrm{L}$ at the U.S. Highway 6 site. Median concentrations were $0.77 \mathrm{mg} / \mathrm{L}$ at 66 th Street and $1.8 \mathrm{mg} / \mathrm{L}$ at U.S. Highway 6 .

Concentrations of dissolved oxygen in more than one-half the samples collected at 66th Street and in about one-third of the samples collected at U.S. Highway 6 on Deadmans Run were equal to or exceeded 100 percent saturation. Concentrations of dissolved oxygen in all but one of the other samples from both sites were at about 100 percent saturation. The reason for the large dissolved-oxygen concentrations is not known.

Values of $\mathrm{pH}$ measured at both sites on Deadmans Run ranged from 7.2 to 8.5. Median values were 7.9 at 66 th Street and 7.6 at U.S. Highway 6 . 


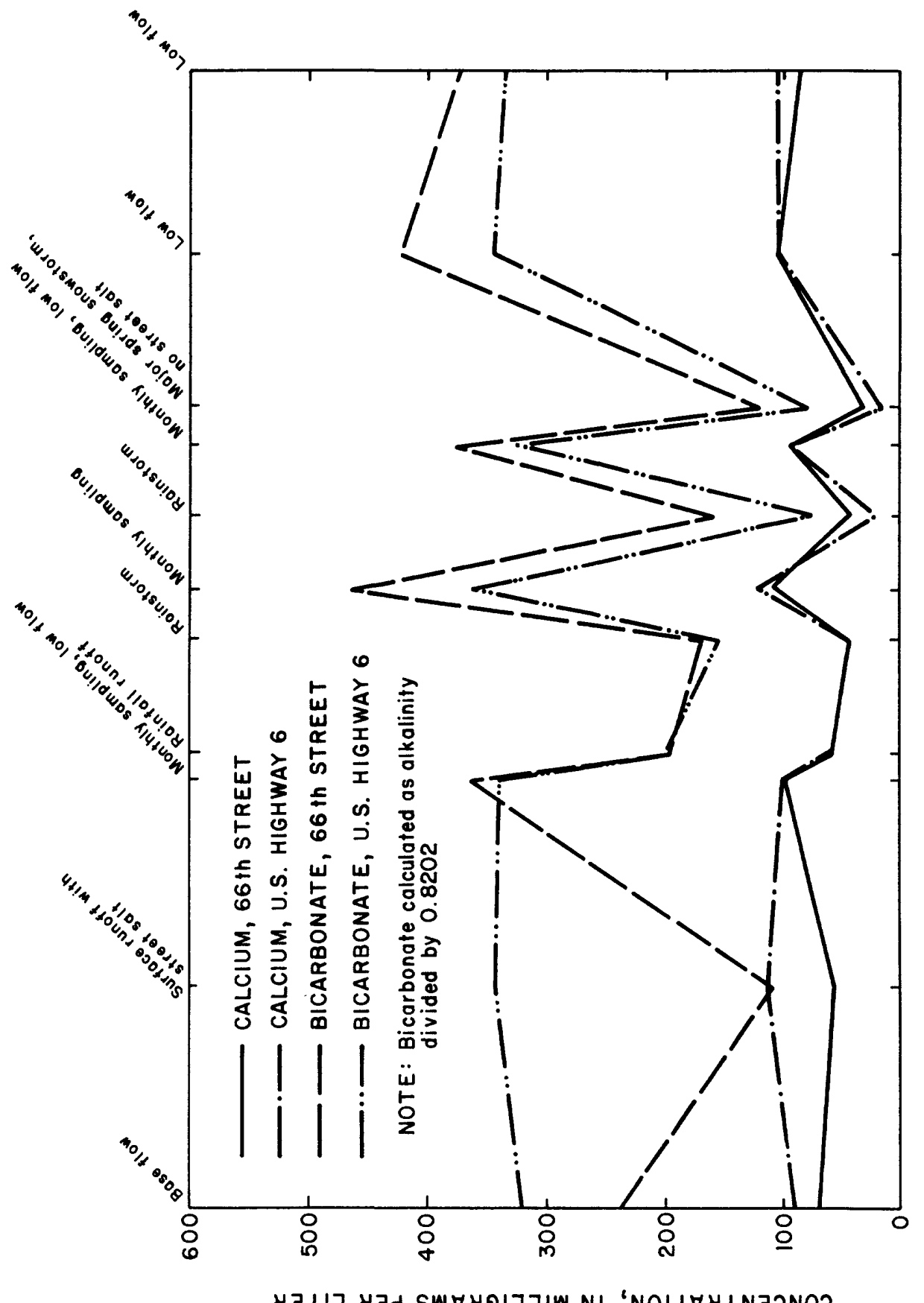

$6 \mathrm{~N} \cap \mathrm{r}$

\) רעd

8 ᄀו마

त्व

$92 \forall \forall w$

$\downarrow 18 \forall W$

S $\forall \forall W$

เ1 835

11 日ココ

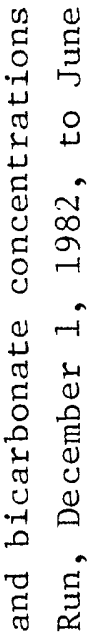

$9 N \forall r$

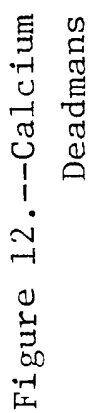

1330

5
0
0
0
0
0

品

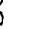

$\infty$

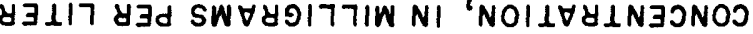


One of the objectives of this study was to determine if the type and concentration of chemical constituents in the stream water could be related to corrosion of channel structures. Structures in both Antelope Creek and Deadmans Run have deteriorated badly in some locations.

Corrosion may be defined broadly as the destruction or deterioration of metal by direct chemical or electrochemical reaction with the environment. Corrosion occurs because in many environments most metals are not inherently stable and tend to revert to a more stable combination; examples of this are the metallic ores found in nature.

Principal channel structures in Antelope Creek and Deadmans Run are limestone-filled steel cages called gabions that are used extensively along the two streams to stabilize their banks. The cages are made of galvanized steel wire, which is wire that has been coated with zinc by the hot-dip process. Zinc applied by the hot-dip process is the best known and most generally used metal coating for iron and steel. Its protective value is nearly proportional to thickness and varies considerably with the environment. In water and underground environments, zinc coatings are less durable as a rule than in the atmosphere, depending on the acidity or alkalinity, the oxygen concentration of the water, and the protective character of the deposits formed by the reaction between the water and the zinc.

Deterioration of the rabions appears to be directly related to their age (Glenn Johnson, Lower Platte Natural Resources District, oral commun., 1984). Regardless of location within either reach, the gabions installed at the earliest time have deteriorated the most.

The environment of the channel structures indicates that the following three types of metal corrosion may be possible: (1) Underwater corrosion, (2) underground corrosion, and (3) stray-current corrosion (electrolysis). These three types of corrosion all were considered with regard to their effect on the deterioration of channel structures in the following ways: (1) The weakening of the zinc-coated wire by reaction with chemical constituents in the stream water, (2) the weakening of the zinccoated wire by the abrasive action of flowing stream sediment, and (3) the electrochemical dissolution of the zinc coating on the wire.

The weakening of the zinc-coated wire by reaction with the chemical constituents in the water initially was thought to be the principal cause of the deterioration of the channel structures. However, based on the concentration of the chemical constituents analyzed (see table 2) and the temperature and $\mathrm{pH}$ of the water, there appear to be no appropriate chemical reactions that could take place between the zinc and these constituents that would greatly weaken the zinc-coated wire. The chemical analyses for this study indicate that, based on quality, the stream water would not be significantly corrosive to galvanized steel. However, if materials should enter the stream that would decrease the $\mathrm{pH}$ to less than 6.0 or increase it to more than 12.0 , rapid corrosion of the zinc might be expected (Speller, 1951). In addition, the movement of water over rills 
and around obstructions causes aeration, which increases the dissolvedoxygen concentration of the stream water. Oxygen usually is essential for substantial corrosion to take place in water.

Weakening of the zinc-coated wire by the abrasive action of sediment in the flowing stream probably is minimal because of the small sediment concentration in the strean water during most of the year. At certain times, large sediment concentrations may contribute partially to the overall problem. Abrasive action of the sediment could remove any protective deposits formed by the reaction between the water and the zinc and scratch or score the galvanized surface.

Electrochemical dissolution of the zinc coating on the steel wire may occur when a current flows from the zinc-coated wire (anode) to another metal or to nonmetal carbon (cathode) through an electrolyte such as salts dissolved in soil water or in streams. The current flowing through the electrolyte may be due to (1) An external electromotive force such as stray current or long-line current; or (2) differences of potential due to the use (presence) of electrodes of different materials or marked variations in the same materials or to dissimilar solutions in contact with the metal (Speller, 1951).

Stray current is that direct or pulsating current that has leaked from an electric-power circuit and flows through the ground and metallic structures that are embedded or partially embedded in the ground. Longline currents are thought to originate from galvanic action or Earth currents due to terrestial magnetism (Speller, 1951). These currents (positive electricity) flow through the ground from an anodic to a cathodic area that returns along an underground metallic structure.

A small current is caused to flow when two dissimilar materials in contact are subrnerged in a saline solution. For example, a metal such as zinc, which is above hydrogen in the electrochemical series and which does not quickly form an impermeable protective coating when placed in solution, will tend to deposit a film of nascent hydrogen on any other more cathodic material with which it is in electrical contact in solution. This causes a flow of current through the metal from the place where the hydrogen film is deposited to the place where the metal is dissolving. The circuit is completed by the flow of current in the opposite direction through the solution.

The inost probable cause for the deterioration of channel structures in Antelope Creek and Deadmans Run may be the flow of stray current within the banks of the streams between the zinc anode and metal or nonmetal that is lower than zinc in the electrochemical series. Current flow probably is conducted by soil water. The passage of current through the circuit may cause the dissolution of zinc. This exposes the underlying steel to oxidation that leads to weakening or deterioration of the steel. 
Geology, precipitation and runoff, and land use are the main factors affecting water-quality variations from place to place and during the year in the two small basins. Because of the small size of the drainage areas, the high flows caused by storms and surface runoff are of short duration. Most of the time the streamflow is maintained at low flows by regulation at upstream reservoirs and by seepage of ground water that usually contains larger concentrations of solutes.

The nature and concentration of the solutes in the ground water are determined by the geologic material through which it passes. If the water comes from the Dakota Formation, it may contain large concentrations of sodium and chloride. If the water is from the unconsolidated deposits, it probably will contain less than $1,000 \mathrm{mg} / \mathrm{L}$ dissolved solids and be of the calcium/bicarbonate type. Based on the chemical analyses made during this study, the principal area where seepage of sodium and chloride water from the Dakota Formation is greatly affecting stream-water quality is the reach on Antelope Creek from 27 th Street to its mouth, and then only during low flows.

During high flows (rainstorm and snowmelt runoff) the stream waters usually contain minimum concentrations of dissolved salts due to dilution by precipitation runoff. However, the noticeably greater concentration of dissolved salts that occasionally occurs in the winter months probably is due to runoff from salted streets.

The cause of corrosion of the rock-filled, galvanized-steel cages used to stabilize the banks of the two stream channels is not readily determined. Based on the chemical analyses of water in the two streams, it appears that water quality is not the major cause of corrosion but may be a catalyst in promoting corrosion. Dissolved oxygen and salts appear to be the prime examples of catalysis for this situation.

A possible cause for the corrosion may be the electrochemical dissolution of the zinc coating on the steel wire of the cages. Dissolution of the zinc may occur if a current flows from the zinc-coated wire (anode) to another metal or nonmetal (cathode) lower in the electrochemical series and completes the circuit through an electrolyte such as salts dissolved in stream or soil water. The passage of current causes the zinc to be dissolved, thus exposing the underlying steel to oxidation and deterioration. 


\section{SELECTED REFERENCES}

Beesley, T. E., and others, 1948, Soil survey, Lancaster County, Nebraska: U.S. Department of Agriculture, ser. 1938 , no. 15,70 p.

Burchett, R. R., 1969, Geologic bedrock map of Nebraska: University of Nebraska, Conservation and Survey Division, scale 1:1,000,000.

City of Lincoln, Nebraska Natural Resources Commission, and Lower Platte South Natural Resources District, 1973, Salt Creek basin--Lincoln Metropolitan Area Water-Quality Management Plan: Lincoln, 237 p.

Condra, G. E., and Reed, E. C., 1939, Deep wells at Lincoln, Nebraska: Nebraska Geological Survey Paper 15, 25 p.

Engberg, R. A., 1980, A statistical analysis of the quality of surface water in Nebraska: U.S. Geological Survey Water-Resources Investigations $80-43,277 \mathrm{p}$.

Goodenkauf, 0., 1978, The ground-water geology of southern Lancaster County, Nebraska: Lincoln, University of Nebraska, Department of Geology, unpublished M.S. thesis, 117 p.

Holly, D. E., 1980, Hydrogeology of northern Lancaster County, Nebraska: Lincoln, University of Nebraska, Department of Geology, unpublished M.S. thesis, $370 \mathrm{p}$.

Kister, L. R., and Mundorff, J. C., 1963, Sedimentation and chemical quality of water in Salt Creek basin, Nebraska: U.S. Geological Survey Water-Supply Paper 1669-I, 47 p.

McKee, J. E., and Wolf, H. W., eds., 1963, Water-quality criteria (2d ed): California State Water Quality Control Board Publication 3-A, 550 p.

Sawyer, C. N., and McCarty, P. L., 1967, Chemistry for sanitary engineers (2d ed.): New York, McGraw-llill Book Co., 518 p.

Speller, F. N., 1951, Corrosion, causes and prevention (3d ed.): New York, McGraw-Hill Book Co., 686 p.

U.S. Environmental Protection Agency, 1976, Quality criteria for water: Washington, D.C., J.S. Government Printing Office, EPA-440/9-76-023, 501 p.

J.S. Geological Survey, published annually, 1964-74, Water resources data for Nebraska--Part 2, Water-quality records: Lincoln, various pagination. 
Table 2.--Water-quality data from three sites on Antelope Creek and two sites on Deadmans Rum, December 1982 througn June 1983 $\left[\mathrm{Ft}^{3} / \mathrm{s}\right.$, cubic feet per second; $\mu \mathrm{S}$, microsiemens per centimeter at $25^{\circ} \mathrm{Celsius;}$ Deg $\mathrm{C}$, degrees Celsius; mg/L, milligrams per liter, $\mu \mathrm{g} / \mathrm{L}$, micrograms per liter]

Antelope Creek at 52d Street

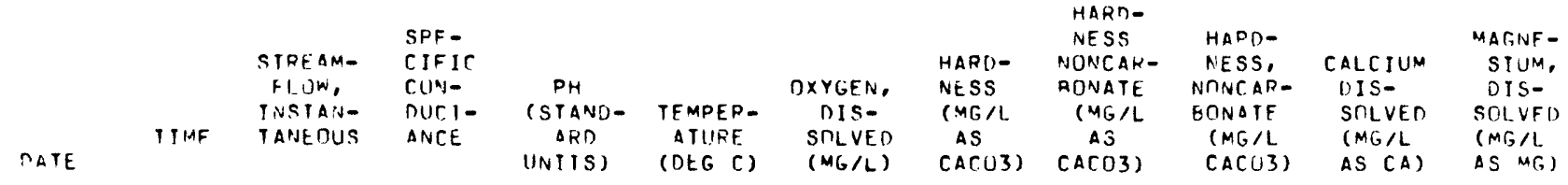

\begin{tabular}{|c|c|c|c|c|c|c|c|c|c|c|c|}
\hline $\mathrm{DFC}$ & & & & & & & & & & & \\
\hline Jais & 1330 & .11 & 905 & 7.6 & 10.5 & 13.6 & 380 & 24 & 24 & 110 & 20 \\
\hline $\operatorname{no}_{\text {FFH }} .$. & 1425 & 3.6 & 1900 & 7.8 & .5 & 17.5 & 150 & 65 & 65 & 48 & 6.8 \\
\hline $\begin{array}{l}10 \ldots \\
14 \ldots \\
\because A R\end{array}$ & $\begin{array}{l}1030 \\
1045\end{array}$ & 3.95 & $\begin{array}{l}500 \\
450\end{array}$ & $\begin{array}{l}\text { A. } 1 \\
\text { R.? }\end{array}$ & $\begin{array}{r}.5 \\
3.0\end{array}$ & $\begin{array}{l}15.5 \\
14.9\end{array}$ & $\begin{array}{l}170 \\
150\end{array}$ & $\begin{array}{l}10 \\
14\end{array}$ & $\begin{array}{l}10 \\
14\end{array}$ & $\begin{array}{l}50 \\
42\end{array}$ & $\begin{array}{l}12 \\
9.9\end{array}$ \\
\hline $\begin{array}{l}0 . . . \\
14 \ldots \\
26 \ldots \\
\Delta D_{n}\end{array}$ & $\begin{array}{l}0915 \\
1040 \\
0945\end{array}$ & $\begin{array}{l}22 \\
2.3 \\
6.4\end{array}$ & $\begin{array}{l}3 R 0 \\
4 A 0 \\
\text { 2RU }\end{array}$ & $\begin{array}{l}8.1 \\
7.9 \\
7.9\end{array}$ & $\begin{array}{r}10.5 \\
6.5 \\
2.0\end{array}$ & $\begin{array}{l}10.9 \\
14.6 \\
14.1\end{array}$ & $\begin{array}{r}130 \\
170 \\
93\end{array}$ & $\begin{array}{l}4 \\
6 \\
2\end{array}$ & $\begin{array}{l}4 \\
6 \\
2\end{array}$ & $\begin{array}{l}38 \\
47 \\
27\end{array}$ & $\begin{array}{c}9.3 \\
12 \\
6.3\end{array}$ \\
\hline $\begin{array}{r}n 7 \ldots \\
13 \ldots \\
M A Y\end{array}$ & $\begin{array}{l}1330 \\
1400\end{array}$ & $13^{6.0}$ & $\begin{array}{l}420 \\
300\end{array}$ & $\begin{array}{l}8.3 \\
8 . ?\end{array}$ & $\begin{array}{l}8.0 \\
6.7\end{array}$ & $\begin{array}{l}13.7 \\
12.8\end{array}$ & $\begin{array}{l}160 \\
100\end{array}$ & $\begin{array}{l}6 \\
1\end{array}$ & $\begin{array}{l}6 \\
1\end{array}$ & $\begin{array}{l}44 \\
30\end{array}$ & $\begin{array}{l}11 \\
0.6\end{array}$ \\
\hline${ }_{\text {JiN }} 0 .$. & 1145 & .30 & $9 h 5$ & 8.1 & 14.0 & 14.2 & 400 & 49 & 49 & 110 & 31 \\
\hline$n \cup \ldots$ & $1>00$ & .23 & 862 & R. 1 & 22.0 & $13 . ?$ & 330 & 30 & 30 & 91 & 20 \\
\hline
\end{tabular}

\begin{tabular}{|c|c|c|c|c|c|c|c|c|c|c|}
\hline & $\begin{array}{l}\text { SONIIIM, } \\
\text { DIS- } \\
\text { SOLVFO } \\
\text { (MG/L }\end{array}$ & $\begin{array}{l}\text { SONIIIM } \\
\text { AO- } \\
\text { SIIRP- } \\
\text { TTON } \\
\text { RATIO }\end{array}$ & PERCFNT & $\begin{array}{l}\text { POTAC- } \\
\text { SIUM, } \\
\text { DIS- } \\
\text { SOIVED } \\
\text { CNG/L }\end{array}$ & $\begin{array}{l}\text { ALKA- } \\
\text { LINITY } \\
\text { LAR } \\
\text { ING/L } \\
\text { AS }\end{array}$ & $\begin{array}{l}\text { SULFATE } \\
\text { DIS- } \\
\text { SOLVED } \\
\text { (MG } / L\end{array}$ & $\begin{array}{l}\text { CHLO- } \\
\text { RIDF, } \\
\text { OIS- } \\
\text { SOLVER } \\
\text { (MG IL }\end{array}$ & $\begin{array}{c}\text { MITKO- } \\
\text { GENA } \\
\text { NOZ+NMZ } \\
\text { OIS- } \\
\text { SULVED } \\
\text { CMG/L }\end{array}$ & $\begin{array}{l}\text { IRUN, } \\
\text { DIS- } \\
\text { SOLVED } \\
\text { I } \mid \text { G IL }\end{array}$ & $\begin{array}{l}\text { MANGA- } \\
\text { NESE, } \\
\text { OIS- } \\
\text { SOLVED } \\
(\mu G / L\end{array}$ \\
\hline ATE & AS N'AI & & STDIUM & $A S K)$ & (ACO3) & AS SO4) & AS (L) & AS N) & AS FE) & $\Delta S \quad M N)$ \\
\hline
\end{tabular}

\begin{tabular}{|c|c|c|c|c|c|c|c|c|c|c|}
\hline \multicolumn{11}{|l|}{ nEC } \\
\hline$\underset{\text { JAAI }}{01} \cdots$ & 51 & 1.2 & 22 & 5.6 & 358 & 100 & 25 & .77 & 22 & 450 \\
\hline $\begin{array}{l}06 \ldots \\
\text { FER }\end{array}$ & $23 n$ & 10 & 70 & 7.7 & 83 & 35 & 490 & .73 & 39 & 200 \\
\hline $\begin{array}{l}10 \ldots \\
14 \ldots \\
M N D\end{array}$ & $\begin{array}{l}32 \\
26\end{array}$ & $\begin{array}{l}1.1 \\
1.0\end{array}$ & $\begin{array}{l}2 R \\
27\end{array}$ & $\begin{array}{l}6.5 \\
6.5\end{array}$ & $\begin{array}{l}165 \\
132\end{array}$ & $\begin{array}{l}47 \\
38\end{array}$ & $\begin{array}{l}31 \\
27\end{array}$ & $\begin{array}{l}1.0 \\
.65\end{array}$ & $\begin{array}{l}24 \\
34\end{array}$ & $\begin{array}{r}170 \\
88\end{array}$ \\
\hline $\begin{array}{c}05 \ldots \\
11 \ldots \\
2 n \ldots \\
\Delta p D\end{array}$ & $\begin{array}{l}19 \\
24 \\
17\end{array}$ & $\begin{array}{r}.7 \\
.8 \\
.8\end{array}$ & $\begin{array}{l}23 \\
23 \\
27\end{array}$ & $\begin{array}{l}5.6 \\
5.8 \\
4.0\end{array}$ & $\begin{array}{r}129 \\
101 \\
9 ?\end{array}$ & $\begin{array}{l}35 \\
48 \\
24\end{array}$ & $\begin{array}{l}16 \\
19 \\
15\end{array}$ & $\begin{array}{r}.74 \\
.85 \\
.62\end{array}$ & $\begin{array}{r}59 \\
39 \\
130\end{array}$ & $\begin{array}{l}42 \\
94 \\
68\end{array}$ \\
\hline $\begin{array}{r}07 \ldots \\
13 \ldots \\
\text { MAY }\end{array}$ & $\begin{array}{l}24 \\
30\end{array}$ & 1.9 & $\begin{array}{l}24 \\
39\end{array}$ & $\begin{array}{l}5.8 \\
3.6\end{array}$ & $\begin{array}{l}149 \\
101\end{array}$ & $\begin{array}{l}40 \\
27\end{array}$ & $\begin{array}{l}16 \\
39\end{array}$ & $\begin{array}{l}1.1 \\
.52\end{array}$ & $\begin{array}{l}64 \\
93\end{array}$ & $\begin{array}{l}43 \\
34\end{array}$ \\
\hline$\underset{J U^{* 1}}{09} \cdots$ & 58 & 1.3 & 24 & 5.3 & 354 & 130 & 34 & 1.5 & 9 & 450 \\
\hline un... & 31 & 1.3 & 25 & 5.6 & 305 & $1 \cap 0$ & 29 & .76 & 14 & 160 \\
\hline
\end{tabular}


Table 2.--Water-quality data from three sites on Antelope Creek and two sites on Deadmans Rum, December 1982 through June 1983--Continued

\section{Antelope Creek at 27th Street}

\begin{tabular}{|c|c|c|c|c|c|c|c|c|c|c|c|}
\hline & TIME & $\begin{array}{l}\text { STREAM- } \\
\text { FLLIW, } \\
\text { INSTAP- } \\
\text { TANE UUS }\end{array}$ & $\begin{array}{l}\text { SPF- } \\
\text { CIFIC } \\
\text { CON- } \\
\text { DUCT- } \\
\triangle N C E\end{array}$ & $\begin{array}{c}\text { PH } \\
\text { (STANI)- } \\
\text { ARD }\end{array}$ & $\begin{array}{c}\text { TFMPER - } \\
\text { ATIIRE }\end{array}$ & $\begin{array}{c}\text { NXYGFN, } \\
\text { DIS- } \\
\text { SOLVEN }\end{array}$ & $\begin{array}{l}\text { HARD- } \\
\text { NESS } \\
\text { (ME/L } \\
\text { AS }\end{array}$ & $\begin{array}{l}\text { HARD- } \\
\text { NFSS } \\
\text { NONCAR- } \\
\text { BONATE } \\
\text { (MG/L } \\
\text { AS }\end{array}$ & $\begin{array}{l}\text { HARD- } \\
\text { NESS, } \\
\text { NONCAR- } \\
\text { BONATF } \\
\text { CMG/L }\end{array}$ & $\begin{array}{l}\text { CALCIUM } \\
\text { OIS- } \\
\text { SOLVEN } \\
\text { (MG/L }\end{array}$ & $\begin{array}{l}\text { MAGNE- } \\
\text { SILIM, } \\
\text { UIS- } \\
\text { SULVEI } \\
\text { CMF, }\end{array}$ \\
\hline ATE & & & & (JNITS) & (nEF, C) & (MG/L) & $(A C 03)$ & $(A C O 3)$ & $(A C O 3)$ & AS (A) & AS $M f_{7}$ ) \\
\hline
\end{tabular}

\begin{tabular}{|c|c|c|c|c|c|c|c|c|c|c|c|}
\hline \multicolumn{12}{|l|}{$D F C$} \\
\hline${ }_{J A N} 1 \ldots$ & 1200 & .21 & 595 & 7.6 & 9.0 & 10.2 & 210 & 11 & 11 & 60 & 14 \\
\hline FEH & 1500 & 9.6 & 1850 & 7.9 & .5 & 17.1 & 150 & 64 & 64 & 50 & 0.7 \\
\hline $\begin{array}{l}10 \ldots \\
14 \ldots \\
\text { MAR }\end{array}$ & $\begin{array}{l}1145 \\
1110\end{array}$ & 2.93 & $\begin{array}{l}710 \\
490\end{array}$ & $\begin{array}{l}\text { R.? } \\
8.1\end{array}$ & 1.5 & $\begin{array}{l}15.0 \\
14.2\end{array}$ & $\begin{array}{l}180 \\
140\end{array}$ & $\begin{array}{l}10 \\
14\end{array}$ & $\begin{array}{l}10 \\
14\end{array}$ & $\begin{array}{l}52 \\
42\end{array}$ & $\begin{array}{l}13 \\
8.9\end{array}$ \\
\hline $\begin{array}{l}05 \ldots \\
14 \ldots \\
20 \ldots \\
\text { APK }\end{array}$ & $\begin{array}{l}0945 \\
1240 \\
1015\end{array}$ & $\begin{array}{l}23 \\
1.8\end{array}$ & $\begin{array}{l}370 \\
490 \\
155\end{array}$ & $\begin{array}{l}\text { A. } 1 \\
\text { ค. } 5 \\
\text { ค. } 2\end{array}$ & $\begin{array}{l}10.5 \\
10.5 \\
1.0\end{array}$ & $\begin{array}{l}10.6 \\
14.7 \\
14.2\end{array}$ & $\begin{array}{r}130 \\
180 \\
44\end{array}$ & $\begin{array}{l}4 \\
8 \\
0\end{array}$ & $\begin{array}{l}4 \\
8 \\
0\end{array}$ & $\begin{array}{l}39 \\
49 \\
14\end{array}$ & $\begin{array}{l}8.9 \\
13 \\
2.2\end{array}$ \\
\hline $\begin{array}{l}07 \ldots \\
13 \ldots \\
\text { MAY }\end{array}$ & $\begin{array}{l}1200 \\
1345\end{array}$ & ${ }_{27}^{8.0}$ & $\begin{array}{l}450 \\
810\end{array}$ & $\begin{array}{l}B .5 \\
\text { ค. } 1\end{array}$ & $\begin{array}{l}0.5 \\
6.3\end{array}$ & $\begin{array}{l}14.2 \\
12.6\end{array}$ & $\begin{array}{r}160 \\
72\end{array}$ & $\begin{array}{l}9 \\
4\end{array}$ & $\begin{array}{l}9 \\
4\end{array}$ & $\begin{array}{l}46 \\
23\end{array}$ & $\begin{array}{l}12 \\
3.0\end{array}$ \\
\hline$\underset{\text { JUN }}{n 9 . . .}$ & 1120 & .40 & $-\infty$ & B. 3 & 13.0 & 12.0 & 320 & 67 & 67 & 90 & 23 \\
\hline $09 .$. & 1245 & 4.5 & 684 & 7.8 & 16.5 & 10.0 & 240 & 31 & 31 & 09 & 10 \\
\hline
\end{tabular}

\begin{tabular}{|c|c|c|c|c|c|c|c|c|c|c|}
\hline & $\begin{array}{l}\text { SODIIIM, } \\
\text { UIS- } \\
\text { SULVED } \\
\text { (MG/L }\end{array}$ & $\begin{array}{l}\text { SODIUM } \\
\text { AD- } \\
\text { SURP- } \\
\text { TION } \\
\text { RATIO }\end{array}$ & PERCENT & $\begin{array}{l}\text { PUTAS- } \\
\text { SIUM, } \\
\text { DIS- } \\
\text { SOLVED } \\
\text { PMG/L }\end{array}$ & $\begin{array}{l}\text { ALKA- } \\
\text { LINITY } \\
\text { LAP } \\
(M G / L \\
A S\end{array}$ & $\begin{array}{l}\text { SIILFATE } \\
\text { DIS- } \\
\text { SOLVED } \\
\text { IMF, }\end{array}$ & $\begin{array}{l}\text { CHLO- } \\
\text { RIDE, } \\
\text { DIS- } \\
\text { SOLVED } \\
\text { (MG/L }\end{array}$ & $\begin{array}{c}\text { NITRC- } \\
\text { GEN } \\
\text { NOZ+NO3 } \\
\text { OIS- } \\
\text { SUIUED } \\
\text { CMG/L }\end{array}$ & $\begin{array}{l}\text { IRON, } \\
\text { DIS- } \\
\text { SULVED } \\
\text { ( } N G / L\end{array}$ & $\begin{array}{l}\text { MANGA- } \\
\text { NESE, } \\
\text { DIS- } \\
\text { SULVED } \\
\text { (J) /L }\end{array}$ \\
\hline ATE & AS NAS & & SnDIUM & AS $K$ ) & $(A C \cap 3)$ & AS SO4) & AS (L) & AS N) & $A S F E)$ & AS MN) \\
\hline
\end{tabular}

\begin{tabular}{|c|c|c|c|c|c|c|c|c|c|c|}
\hline DER & & & & & & & & & & \\
\hline $01 \ldots$ & un & 1.3 & 29 & 7.7 & 197 & 67 & 29 & .48 & 33 & 43 \\
\hline FE... & 290 & 11 & 79 & 9.9 & 89 & 37 & 490 & 1.3 & 34 & 120 \\
\hline $\begin{array}{l}10 \ldots \\
14 \ldots \\
M A R\end{array}$ & $\begin{array}{l}6 R \\
4 n\end{array}$ & $\begin{array}{l}2.3 \\
1.5\end{array}$ & $\begin{array}{l}44 \\
37\end{array}$ & $\begin{array}{l}6.6 \\
6.1\end{array}$ & $\begin{array}{l}174 \\
128\end{array}$ & $\begin{array}{l}55 \\
39\end{array}$ & $\begin{array}{l}87 \\
59\end{array}$ & $\begin{array}{l}1.0 \\
.04\end{array}$ & $\begin{array}{l}14 \\
20\end{array}$ & $\begin{array}{r}110 \\
03\end{array}$ \\
\hline $\begin{array}{l}05 \ldots \\
14 \ldots \\
26 \ldots \\
A P R\end{array}$ & $\begin{array}{l}21 \\
28 \\
9.3\end{array}$ & $\begin{array}{r}.8 \\
1.0 \\
.6\end{array}$ & $\begin{array}{l}24 \\
25 \\
30\end{array}$ & $\begin{array}{l}5.8 \\
5.9 \\
2.1\end{array}$ & $\begin{array}{r}130 \\
168 \\
48\end{array}$ & $\begin{array}{l}37 \\
53 \\
11\end{array}$ & $\begin{array}{l}18 \\
19 \\
11\end{array}$ & $\begin{array}{l}.83 \\
.75 \\
.47\end{array}$ & $\begin{array}{r}79 \\
25 \\
130\end{array}$ & $\begin{array}{l}38 \\
50 \\
27\end{array}$ \\
\hline $\begin{array}{l}07 \ldots \\
13 \ldots \\
M_{A Y}\end{array}$ & $\begin{array}{r}25 \\
110\end{array}$ & 5.9 & $\begin{array}{l}24 \\
76\end{array}$ & $\begin{array}{l}5.7 \\
2.5\end{array}$ & $\begin{array}{r}156 \\
68\end{array}$ & $\begin{array}{l}49 \\
16\end{array}$ & $\begin{array}{r}18 \\
190\end{array}$ & $\begin{array}{l}1.1 \\
.34\end{array}$ & $\begin{array}{r}100 \\
71\end{array}$ & $\begin{array}{l}41 \\
30\end{array}$ \\
\hline $\operatorname{JIIN}_{\text {UQN }}^{0}$ & 71 & 1.8 & 32 & 6.6 & 253 & 100 & 87 & $4 . ?$ & 5 & 50 \\
\hline $00 \ldots$ & 44 & 1.3 & 28 & 6.6 & 208 & 86 & 25 & 1.4 & 17 & 29 \\
\hline
\end{tabular}


Table 2.--Water-quality data from three sites on Antelope Creek and two sites on Deadmans Rum, December 1982 through June 1983- Continued

\section{Antelope Creek at Court Street}

\begin{tabular}{|c|c|c|c|c|c|c|c|c|c|c|c|}
\hline & TIMF & $\begin{array}{l}\text { STREAN- } \\
\text { FL IIV: } \\
\text { INSTAN- } \\
\text { TANEOUS }\end{array}$ & $\begin{array}{l}\text { SPF- } \\
\text { CIFIC } \\
\text { CON- } \\
\text { DUCT- } \\
\text { ANCE }\end{array}$ & $\begin{array}{c}\text { PH } \\
\text { (STANU- } \\
\text { ARD }\end{array}$ & $\begin{array}{l}\text { TEMPER- } \\
\text { ATURF }\end{array}$ & $\begin{array}{c}\text { OXYGFN, } \\
\text { OIS- } \\
\text { SOLVEN }\end{array}$ & $\begin{array}{l}\text { HARD- } \\
\text { NESS } \\
\text { (MG/L } \\
\text { AS }\end{array}$ & $\begin{array}{l}\text { NAKSS } \\
\text { NONCAK- } \\
\text { RONATE } \\
\text { (MG/L } \\
\text { AS }\end{array}$ & $\begin{array}{l}\text { HARO- } \\
\text { NESS, } \\
\text { NONCAR- } \\
\text { BOINATE } \\
\text { (ME/L }\end{array}$ & $\begin{array}{l}\text { CALCIUM } \\
\text { UIS- } \\
\text { SOLVER } \\
\text { IMG/L }\end{array}$ & $\begin{array}{l}\text { MAFNF- } \\
\text { SIUN, } \\
\text { DIS- } \\
\text { SULVEL } \\
\text { (MG/L }\end{array}$ \\
\hline TE & & & & (INITS) & (DEC, C) & $(M G / L)$ & $(A C \cup 3)$ & $(A C \cup 3)$ & $(A(03)$ & $A S(A)$ & AS MG) \\
\hline
\end{tabular}

\begin{tabular}{|c|c|c|c|c|c|c|c|c|c|c|c|}
\hline \multicolumn{12}{|l|}{$D F C$} \\
\hline JAN & $090 n$ & 1.0 & 6700 & 7.2 & 9.0 & 9.0 & 380 & 135 & 135 & 100 & 32 \\
\hline$\underset{F E H}{0 .} \ldots$ & 1530 & $1^{A}$ & 1950 & 8.2 & 3.5 & 15.5 & 160 & 76 & 76 & 53 & 7.5 \\
\hline $\begin{array}{l}10 \ldots \\
14 \ldots \\
\text { MAR }\end{array}$ & $\begin{array}{l}1345 \\
1145\end{array}$ & $\begin{array}{l}1.9 \\
5.8\end{array}$ & $\begin{array}{l}4100 \\
1750\end{array}$ & $\begin{array}{l}7.9 \\
9.1\end{array}$ & $\begin{array}{l}5.0 \\
5.5\end{array}$ & $\begin{array}{l}15.2 \\
14.3\end{array}$ & $\begin{array}{l}340 \\
170\end{array}$ & $\begin{array}{r}130 \\
38\end{array}$ & $\begin{array}{r}130 \\
38\end{array}$ & $\begin{array}{l}96 \\
50\end{array}$ & $\begin{array}{l}25 \\
12\end{array}$ \\
\hline $\begin{array}{l}05 \ldots \\
14 \ldots \\
26 \ldots \\
\text { APR }\end{array}$ & $\begin{array}{l}1000 \\
1330 \\
1030\end{array}$ & $\begin{array}{l}30 \\
3.0 \\
23\end{array}$ & $\begin{array}{r}590 \\
3200 \\
370\end{array}$ & $\begin{array}{l}7.9 \\
7.7 \\
8.0\end{array}$ & $\begin{array}{r}11.5 \\
10.0 \\
1.0\end{array}$ & $\begin{array}{r}9.8 \\
14.5 \\
13.6\end{array}$ & $\begin{array}{r}120 \\
260 \\
51\end{array}$ & $\begin{array}{r}7 \\
52 \\
0\end{array}$ & $\begin{array}{r}7 \\
52 \\
0\end{array}$ & $\begin{array}{l}35 \\
70 \\
16\end{array}$ & $\begin{array}{l}7.9 \\
20 \\
2.6\end{array}$ \\
\hline $\begin{array}{l}07 \ldots \\
13 \ldots \\
\text { MAr }\end{array}$ & $\begin{array}{l}0930 \\
1300\end{array}$ & ${ }_{44}^{8.9}$ & $\begin{array}{l}1360 \\
1390\end{array}$ & $\begin{array}{l}R .2 \\
R .0\end{array}$ & $\begin{array}{l}5.5 \\
5.5\end{array}$ & $\begin{array}{l}15.2 \\
12.4\end{array}$ & $\begin{array}{r}190 \\
93\end{array}$ & $\begin{array}{l}24 \\
27\end{array}$ & $\begin{array}{l}24 \\
27\end{array}$ & $\begin{array}{l}53 \\
30\end{array}$ & $\begin{array}{l}15 \\
4.5\end{array}$ \\
\hline$\underset{J 1 N}{n 9} \ldots$ & 1045 & 1.2 & 6000 & 7.9 & 14.0 & 12.0 & 440 & 186 & 186 & 120 & 33 \\
\hline$\cap 9 .$. & 1345 & 5.6 & 1030 & 8.6 & 22.0 & 17.4 & 250 & 65 & 65 & 73 & 17 \\
\hline
\end{tabular}

\begin{tabular}{|c|c|c|c|c|c|c|c|c|c|c|}
\hline & $\begin{array}{l}\text { SUDIIJM, } \\
\text { DIS- } \\
\text { SOLVED } \\
\text { (MG/L }\end{array}$ & $\begin{array}{l}\text { SUDIUM } \\
\text { AD- } \\
\text { SUPP- } \\
\text { TION } \\
\text { RATIO }\end{array}$ & PERCFNT & $\begin{array}{l}\text { POTAS- } \\
\text { SIUM, } \\
\text { DIS- } \\
\text { SOLVED } \\
\text { CMG/L }\end{array}$ & $\begin{array}{l}\Delta L K A- \\
\text { LINITY } \\
L A R \\
(M G / L \\
\Delta S\end{array}$ & $\begin{array}{l}\text { SIJLFATE } \\
\text { DIS- } \\
\text { SOLVED } \\
\text { (WG,L }\end{array}$ & $\begin{array}{l}\text { CHLO- } \\
\text { RIDE, } \\
\text { DIS- } \\
\text { SOLVED } \\
\text { (MG/L }\end{array}$ & $\begin{array}{l}\text { NITRC- } \\
\text { GFN. } \\
\text { NOZ+NOZ } \\
\text { OIS- } \\
\text { SOLVED } \\
\text { CMG/L }\end{array}$ & $\begin{array}{l}\text { IRON, } \\
\text { DIS- } \\
\text { SOLVED } \\
\text { C } \perp G / L\end{array}$ & $\begin{array}{l}\text { MANGA- } \\
\text { NESE, } \\
\text { UIS- } \\
\text { SULVED } \\
\text { (NG/L }\end{array}$ \\
\hline ATE & AS NA) & & SกUIUM & AS $(x)$ & $(A C \cap 3)$ & AS S(O4) & AS (L) & $A S N)$ & $A S F E)$ & $\triangle S M N)$ \\
\hline
\end{tabular}

\begin{tabular}{|c|c|c|c|c|c|c|c|c|c|c|}
\hline \multicolumn{11}{|l|}{ DEr } \\
\hline$\underset{\text { JAN }}{01} \cdots$ & 1300 & 30 & $8 B$ & 11 & 207 & 330 & 1900 & 3.8 & 50 & 300 \\
\hline$\underset{F E R}{O H} \cdots$ & 310 & 11 & 79 & 9.7 & 87 & 54 & 540 & 1.1 & 28 & 82 \\
\hline $\begin{array}{l}i_{1} \ldots \\
14 \ldots \\
\text { MAR }\end{array}$ & $\begin{array}{l}680 \\
280\end{array}$ & $\begin{array}{l}17 \\
9.6\end{array}$ & $\begin{array}{l}81 \\
77\end{array}$ & $\begin{array}{l}8.9 \\
0.9\end{array}$ & $\begin{array}{l}213 \\
137\end{array}$ & $\begin{array}{r}200 \\
00\end{array}$ & $\begin{array}{r}1000 \\
390\end{array}$ & $\begin{array}{l}2.5 \\
1.5\end{array}$ & $\begin{array}{l}10 \\
37\end{array}$ & $\begin{array}{l}180 \\
110\end{array}$ \\
\hline $\begin{array}{l}05 \ldots \\
14 \ldots \\
26 \ldots \\
\triangle P R\end{array}$ & $\begin{array}{r}58 \\
500 \\
43\end{array}$ & $\begin{array}{r}2.4 \\
14 \\
2.7\end{array}$ & $\begin{array}{l}50 \\
80 \\
64\end{array}$ & $\begin{array}{l}5.3 \\
7.8 \\
2.0\end{array}$ & $\begin{array}{r}113 \\
206 \\
51\end{array}$ & $\begin{array}{r}44 \\
170 \\
21\end{array}$ & $\begin{array}{r}80 \\
760 \\
65\end{array}$ & $\begin{array}{l}1.0 \\
1.9 \\
.75\end{array}$ & $\begin{array}{r}12 \\
20 \\
110\end{array}$ & $\begin{array}{r}33 \\
120 \\
36\end{array}$ \\
\hline $\begin{array}{l}07 \ldots \\
17 \ldots \\
\text { MAY } \cdots\end{array}$ & $\begin{array}{l}180 \\
>10\end{array}$ & $\begin{array}{l}5.8 \\
9.9\end{array}$ & $\begin{array}{l}66 \\
8 ?\end{array}$ & $\begin{array}{l}6.2 \\
3.1\end{array}$ & $\begin{array}{r}170 \\
67\end{array}$ & $\begin{array}{l}94 \\
24\end{array}$ & $\begin{array}{l}200 \\
310\end{array}$ & $\begin{array}{l}1.7 \\
.47\end{array}$ & $\begin{array}{l}63 \\
31\end{array}$ & $\begin{array}{l}68 \\
40\end{array}$ \\
\hline$\underset{\text { JUN }}{0^{\circ}} \cdots$ & 1000 & 22 & 83 & 11 & 250 & 350 & 1500 & 2.9 & 40 & $2 P_{0}$ \\
\hline $09 \ldots$ & 100 & 2.8 & 45 & 7.9 & $18 R$ & 130 & $12^{n}$ & 1.1 & 10 & 51 \\
\hline
\end{tabular}


Table 2.--Water-quality data from three sites on Antelope Creek and two sites on Deadmans Run, December 1982 through June 1983--Continued

Deadmans Run at 66 th Street

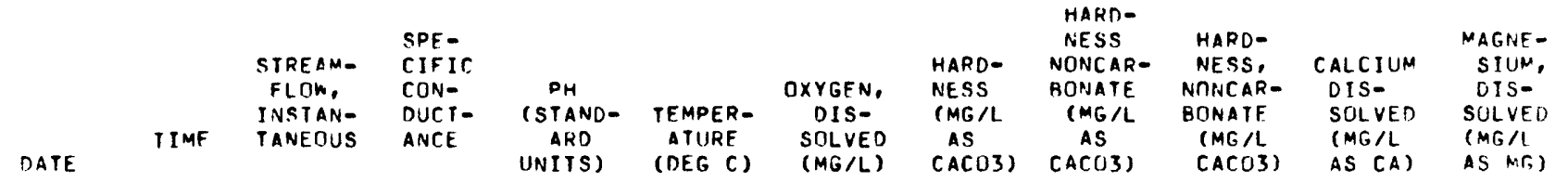

\begin{tabular}{|c|c|c|c|c|c|c|c|c|c|c|c|}
\hline \multicolumn{12}{|l|}{ DFC } \\
\hline${ }_{J A N} 1 \ldots$ & 1010 & 1.4 & 645 & 7.2 & 10.5 & 10.6 & 220 & 28 & 28 & 67 & 14 \\
\hline $\begin{array}{l}06 \ldots \\
\text { FEB }\end{array}$ & 1350 & 7.5 & 1650 & 7.8 & 2.0 & 16.7 & 170 & 81 & 81 & 56 & 7.2 \\
\hline $\begin{array}{l}11 \ldots \\
14 \ldots \\
\text { MAR }\end{array}$ & $\begin{array}{l}1045 \\
1015\end{array}$ & 3.37 & $\begin{array}{r}1600 \\
800\end{array}$ & $\begin{array}{l}7.8 \\
7.8\end{array}$ & $\begin{array}{l}1.5 \\
2.5\end{array}$ & $\begin{array}{l}12.4 \\
13.4\end{array}$ & $\begin{array}{l}350 \\
190\end{array}$ & $\begin{array}{l}50 \\
31\end{array}$ & $\begin{array}{l}50 \\
31\end{array}$ & $\begin{array}{l}99 \\
55\end{array}$ & $\begin{array}{l}24 \\
13\end{array}$ \\
\hline $\begin{array}{r}05 \ldots \\
14 \ldots \\
26 \ldots \\
A P R\end{array}$ & $\begin{array}{l}0845 \\
1000 \\
0915\end{array}$ & $\begin{array}{c}9.1 \\
25^{.40}\end{array}$ & $\begin{array}{r}570 \\
1080 \\
540\end{array}$ & $\begin{array}{l}7.9 \\
7.9 \\
8 . ?\end{array}$ & $\begin{array}{r}12.0 \\
7.0 \\
2.0\end{array}$ & $\begin{array}{l}10.0 \\
14.3 \\
14.1\end{array}$ & $\begin{array}{l}150 \\
400 \\
140\end{array}$ & $\begin{array}{l}11 \\
24 \\
13\end{array}$ & $\begin{array}{l}11 \\
24 \\
13\end{array}$ & $\begin{array}{r}43 \\
110 \\
40\end{array}$ & $\begin{array}{c}9.8 \\
31 \\
9.9\end{array}$ \\
\hline $08 \ldots$ & $\begin{array}{l}0930 \\
1335\end{array}$ & $27^{.97}$ & $\begin{array}{l}920 \\
445\end{array}$ & $\begin{array}{l}8.5 \\
7.7\end{array}$ & $\begin{array}{l}6.0 \\
1.5\end{array}$ & $\begin{array}{l}13.0 \\
11.4\end{array}$ & $\begin{array}{r}330 \\
98\end{array}$ & $\begin{array}{r}22 \\
4\end{array}$ & $\begin{array}{r}22 \\
4\end{array}$ & $\begin{array}{l}92 \\
29\end{array}$ & $\begin{array}{l}24 \\
6.1\end{array}$ \\
\hline MAY & & & & & & & & & & & \\
\hline JUN & 0915 & .80 & 960 & 8.0 & 11.5 & 13.1 & 370 & 21 & 21 & 100 & 28 \\
\hline $09 \ldots$ & 1515 & .42 & 902 & 8.3 & 26.5 & 16.0 & 320 & 15 & 15 & 85 & 20 \\
\hline
\end{tabular}

\begin{tabular}{|c|c|c|c|c|c|c|c|c|c|c|}
\hline & $\begin{array}{l}\text { SODIIIM, } \\
\text { DIS- } \\
\text { SOLVED } \\
\text { IMG/L }\end{array}$ & $\begin{array}{l}\text { SUDIUPA } \\
\text { AD- } \\
\text { SURP- } \\
\text { TION } \\
\text { RATIO }\end{array}$ & PEPCENT & $\begin{array}{l}\text { POTAS- } \\
\text { SIUM, } \\
\text { DIS- } \\
\text { SOLVED } \\
\text { TMG/L }\end{array}$ & $\begin{array}{l}\text { ALKA- } \\
\text { LINITY } \\
\text { LAR } \\
\text { CMG/L } \\
\text { AS }\end{array}$ & $\begin{array}{l}\text { SULFATE } \\
\text { DIS- } \\
\text { SOLVED } \\
\text { IMG/L }\end{array}$ & $\begin{array}{l}\text { CHLN- } \\
\text { RIDE. } \\
\text { DIS- } \\
\text { SOLVEN } \\
\text { CME/L }\end{array}$ & $\begin{array}{l}\text { NITRO- } \\
\text { GEN, } \\
\text { NOZ } 2+N O 3 \\
\text { DIS- } \\
\text { SOLVEU } \\
\text { IMC, }\end{array}$ & $\begin{array}{l}\text { IRUN, } \\
\text { DIS- } \\
\text { SOLVED } \\
\text { (NG/L }\end{array}$ & $\begin{array}{l}\text { MANGA- } \\
\text { NESE, } \\
\text { DIS- } \\
\text { SOLVEO } \\
\text { (UG } / L\end{array}$ \\
\hline ATE & AS NA) & & SODIUM & AS KJ & $(A C \cap 3)$ & AS S(4) & AS (L) & AS N) & AS FE) & AS MN) \\
\hline
\end{tabular}

\begin{tabular}{|c|c|c|c|c|c|c|c|c|c|c|}
\hline JAN & 46 & 1.4 & 30 & 4.8 & 197 & 55 & 58 & .54 & 14 & 120 \\
\hline FER & 220 & 7.7 & 73 & 8.1 & 89 & 30 & 410 & .77 & 23 & 120 \\
\hline $\begin{array}{l}11 \ldots \\
14 \ldots \\
M A R\end{array}$ & $\begin{array}{r}200 \\
75\end{array}$ & $\begin{array}{l}4.9 \\
2.5\end{array}$ & $\begin{array}{l}55 \\
45\end{array}$ & $\begin{array}{l}5.5 \\
5.7\end{array}$ & $\begin{array}{l}297 \\
160\end{array}$ & $\begin{array}{l}98 \\
48\end{array}$ & $\begin{array}{l}280 \\
120\end{array}$ & $\begin{array}{l}2.0 \\
.85\end{array}$ & $\begin{array}{r}11 \\
130\end{array}$ & $\begin{array}{l}470 \\
330\end{array}$ \\
\hline $\begin{array}{r}05 \ldots \\
14 \ldots \\
26 \ldots \\
A P R\end{array}$ & $\begin{array}{l}43 \\
76 \\
46\end{array}$ & $\begin{array}{l}1.6 \\
1.7 \\
1.8\end{array}$ & $\begin{array}{l}38 \\
29 \\
41\end{array}$ & $\begin{array}{l}4.1 \\
4.1 \\
3.5\end{array}$ & $\begin{array}{l}137 \\
379 \\
128\end{array}$ & $\begin{array}{r}32 \\
120 \\
33\end{array}$ & $\begin{array}{l}67 \\
55 \\
72\end{array}$ & $\begin{array}{l}.45 \\
1.6 \\
.20\end{array}$ & $\begin{array}{r}64 \\
7 \\
37\end{array}$ & $\begin{array}{r}96 \\
380 \\
34\end{array}$ \\
\hline $\begin{array}{l}O R \\
14 \ldots \\
\text { MAY }\end{array}$ & $\begin{array}{l}04 \\
4 R\end{array}$ & $\begin{array}{l}1.6 \\
2.2\end{array}$ & $\begin{array}{l}29 \\
51\end{array}$ & $\begin{array}{l}3.8 \\
2.8\end{array}$ & $\begin{array}{r}307 \\
94\end{array}$ & $\begin{array}{l}91 \\
20\end{array}$ & $\begin{array}{l}50 \\
70\end{array}$ & $\begin{array}{l}1.3 \\
.27\end{array}$ & $\begin{array}{r}7 \\
95\end{array}$ & $\begin{array}{r}300 \\
36\end{array}$ \\
\hline $\operatorname{JUN}^{09} \cdots$ & 67 & 1.6 & 28 & 4.3 & 345 & 110 & 45 & 1.8 & 6 & 230 \\
\hline $0^{9} \ldots$ & 66 & 1.7 & 31 & 4.9 & 305 & 100 & 43 & .64 & 22 & 98 \\
\hline
\end{tabular}


Table 2.--Water-quality data from three sites on Antelope Creek and two sites on Deadmans Run, December 1982 through June 1983--Continued

Deadmans Rem at U.S. Highway 6

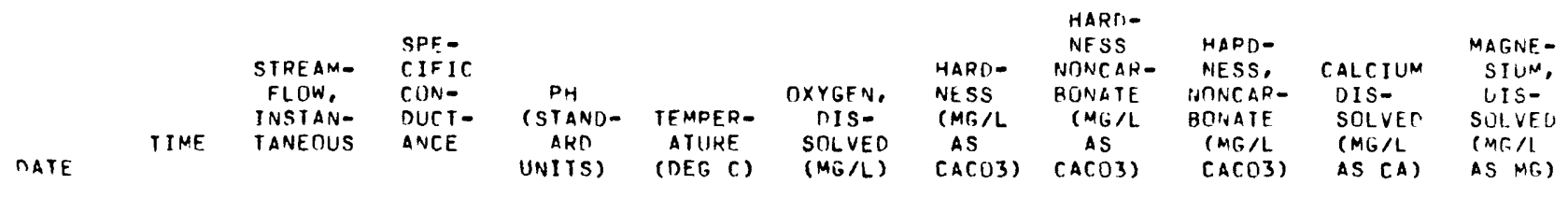

\begin{tabular}{|c|c|c|c|c|c|c|c|c|c|c|c|}
\hline \multicolumn{12}{|l|}{ CEC } \\
\hline JAN $01 \cdots$ & 1030 & 1.6 & 1140 & -- & 8.5 & -- & 310 & 51 & 51 & 90 & 21 \\
\hline No... & 1315 & 3.7 & 1900 & 7.5 & 5.0 & 13.6 & 370 & 92 & 92 & 110 & 24 \\
\hline $\begin{array}{r}11 \ldots \\
14 \ldots \\
\text { MAR }\end{array}$ & $\begin{array}{l}1130 \\
1215\end{array}$ & $\begin{array}{l}2.2 \\
7.2\end{array}$ & $\begin{array}{r}1900 \\
900\end{array}$ & $\begin{array}{l}7 . a \\
7.6\end{array}$ & $\begin{array}{l}4.0 \\
5.0\end{array}$ & $\begin{array}{l}12.0 \\
13.2\end{array}$ & $\begin{array}{l}350 \\
200\end{array}$ & $\begin{array}{l}70 \\
32\end{array}$ & $\begin{array}{l}70 \\
32\end{array}$ & $\begin{array}{r}100 \\
57\end{array}$ & $\begin{array}{l}24 \\
13\end{array}$ \\
\hline $\begin{array}{l}05 \ldots \\
14 \ldots \\
20 \ldots \\
A P R\end{array}$ & $\begin{array}{l}1100 \\
0900 \\
1110\end{array}$ & $\begin{array}{c}13 \\
2.2 \\
20\end{array}$ & $\begin{array}{r}580 \\
2850 \\
245\end{array}$ & $\begin{array}{l}7.8 \\
7.4 \\
7.8\end{array}$ & $\begin{array}{r}12.5 \\
8.5 \\
.5\end{array}$ & $\begin{array}{r}9.9 \\
9.9 \\
13.6\end{array}$ & $\begin{array}{r}140 \\
410 \\
62\end{array}$ & $\begin{array}{r}16 \\
122 \\
1\end{array}$ & $\begin{array}{r}16 \\
122 \\
1\end{array}$ & $\begin{array}{r}43 \\
120 \\
19\end{array}$ & $\begin{array}{c}8.8 \\
28 \\
3.6\end{array}$ \\
\hline $\begin{array}{l}08 \ldots \\
14 \ldots \\
\text { MAY }\end{array}$ & $\begin{array}{l}1030 \\
1430\end{array}$ & $63^{2.7}$ & $\begin{array}{r}1400 \\
770\end{array}$ & $\begin{array}{l}7.9 \\
7.7\end{array}$ & $\begin{array}{l}8.5 \\
4.5\end{array}$ & $\begin{array}{l}11.2 \\
10.6\end{array}$ & $\begin{array}{r}320 \\
73\end{array}$ & 61 & $\begin{array}{r}61 \\
9\end{array}$ & $\begin{array}{l}92 \\
24\end{array}$ & $\begin{array}{l}23 \\
3.2\end{array}$ \\
\hline $\begin{array}{l}09 . . \\
\operatorname{JUN}\end{array}$ & 1015 & 2.9 & 1540 & 7.6 & 13.0 & 11.5 & 360 & 76 & 76 & 100 & 20 \\
\hline n9... & 1430 & 2.4 & 1780 & 7.8 & 22.0 & 10.6 & 360 & 84 & 84 & 100 & 26 \\
\hline
\end{tabular}

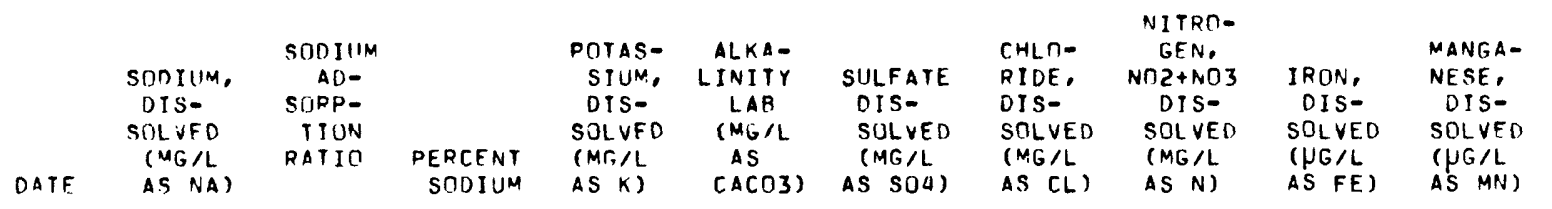

\begin{tabular}{|c|c|c|c|c|c|c|c|c|c|c|}
\hline $\begin{array}{l}\text { DEC } \\
01 \ldots \\
\text { JAN }\end{array}$ & 110 & 2.8 & 43 & 6.5 & 261 & 91 & 150 & 1.9 & 34 & 340 \\
\hline$\underset{\text { FEA }}{06} \ldots$ & $? 40$ & 5.6 & 58 & 7.7 & 282 & 110 & $38 n$ & 1.9 & 23 & 380 \\
\hline $\begin{array}{l}11 \ldots \\
14 \ldots \\
M A R\end{array}$ & $\begin{array}{r}260 \\
94\end{array}$ & $\begin{array}{l}6.3 \\
3.0\end{array}$ & $\begin{array}{l}61 \\
50\end{array}$ & $\begin{array}{l}6.7 \\
5.7\end{array}$ & $\begin{array}{l}279 \\
164\end{array}$ & $\begin{array}{r}120 \\
50\end{array}$ & $\begin{array}{l}390 \\
140\end{array}$ & $\begin{array}{l}1.8 \\
.98\end{array}$ & $\begin{array}{l}11 \\
38\end{array}$ & $\begin{array}{l}380 \\
290\end{array}$ \\
\hline $\begin{array}{l}05 \ldots \\
14 \ldots \\
26 \ldots \\
A P R\end{array}$ & $\begin{array}{r}46 \\
420 \\
10\end{array}$ & $\begin{array}{l}1.7 \\
9.3 \\
1.1\end{array}$ & $\begin{array}{l}40 \\
68 \\
39\end{array}$ & $\begin{array}{l}4.4 \\
6.8 \\
2.2\end{array}$ & $\begin{array}{r}128 \\
294 \\
61\end{array}$ & $\begin{array}{r}32 \\
160 \\
16\end{array}$ & $\begin{array}{r}67 \\
610 \\
26\end{array}$ & $\begin{array}{r}.65 \\
1.7 \\
.58\end{array}$ & $\begin{array}{r}57 \\
10 \\
110\end{array}$ & $\begin{array}{r}71 \\
330 \\
53\end{array}$ \\
\hline $\begin{array}{l}O B \ldots \\
14 \ldots \\
\text { NAY }\end{array}$ & $\begin{array}{l}150 \\
120\end{array}$ & $\begin{array}{l}3.8 \\
6.4\end{array}$ & $\begin{array}{l}50 \\
77\end{array}$ & $\begin{array}{l}5.3 \\
3.1\end{array}$ & $\begin{array}{r}204 \\
64\end{array}$ & $\begin{array}{r}100 \\
13\end{array}$ & $\begin{array}{l}220 \\
190\end{array}$ & $\begin{array}{l}1.9 \\
.41\end{array}$ & $\begin{array}{r}8 \\
85\end{array}$ & $\begin{array}{r}410 \\
57\end{array}$ \\
\hline$\underset{\text { JUN }}{09} \cdot$. & 180 & 4.3 & 52 & 6.3 & 281 & 110 & 250 & 2.3 & 8 & 460 \\
\hline $09 \ldots$ & 210 & 5.0 & 56 & 7.2 & 273 & 120 & 280 & 1.9 & 12 & 330 \\
\hline
\end{tabular}




\section{Specific-Conductance Surveys}

Table 3.--Specific-conductance survey of Antelope Creek main channel from Holmes Lake outlet to Fairgrounds bridge west of Bob Devaney Sports Center and principal tributaries or outfalls, December 1, 1982

$$
\left[\mu \mathrm{S} / \mathrm{cm}, \text { microsiemens per centimeter at } 25^{\circ}\right. \text { Celsius] }
$$

\begin{tabular}{|c|c|c|}
\hline Location & $\begin{array}{c}\text { Specific } \\
\text { conductance } \\
(\mu \mathrm{S} / \mathrm{cm})\end{array}$ & $\begin{array}{c}\mathrm{pH} \\
\text { (units) } \\
\end{array}$ \\
\hline Main channel at Holmes Lake outlet- & 546 & 8.25 \\
\hline Creek from south, between 56 th Street and dam- & 696 & 7.95 \\
\hline Creek from north, between $56 \mathrm{th}$ Street and dam- & 666 & 8.20 \\
\hline Main channel at $56 \mathrm{th}$ Street- & 864 & 8.20 \\
\hline Main channel at bike trail at $52 \mathrm{~d}$ Street- & 905 & 8.20 \\
\hline Main channel at $48 \mathrm{th}$ Street- & 969 & 8.00 \\
\hline Main channel at Eden Park swimming pool- & 956 & 8.05 \\
\hline Main channel at 40 th Street- & 818 & 8.25 \\
\hline Main channel at South Street- & 893 & 8.25 \\
\hline Main channel at Elks Field- & 946 & 8.20 \\
\hline Main channel at A Street-- & 955 & 8.10 \\
\hline Main channel at 27 th Street- & 974 & 7.90 \\
\hline Main channel at $J$ Street- & 662 & 7.75 \\
\hline $\begin{array}{l}\text { Main channel inflow to tunnel at } M \text { Street- } \\
\text { Main channel at outlet from tunnel north of Vine }\end{array}$ & 566 & 7.85 \\
\hline Street- & 2,580 & 7.60 \\
\hline Large outfall near Cushman-OMC Plant- & 363 & 7.60 \\
\hline Outfall upstream near Cushman-OMC Plant- & 498 & 8.10 \\
\hline Outfall by R.R. bridge near Cushman-OMC Plant-- & 507 & 8.20 \\
\hline Main channel at R.R. bridge near Cushman-OMC Plant-- & 2,290 & 7.75 \\
\hline Main channe1 at 17 th Street (at gage) & 2,230 & 7.80 \\
\hline Outfall at 16th Street- & 597 & 7.45 \\
\hline Main channel at Court Street- & 5,150 & 7.60 \\
\hline Main channel at Fairgrounds bridge- & 8,700 & 7.95 \\
\hline Outfall at Fairgrounds bridge- & 477 & 7.05 \\
\hline
\end{tabular}


Table 4.--Specific-conductance survey of water from Antelope Creek main channel and from drains into Antelope Creek tunnel and seeps into cement-lined channel, May 9, 10, 1983

[Area covered included reach from entrance to tunnel upstream from $\mathrm{N}$ Street to end of cement-lined channel downstream from Court Street by Bob Devaney Sports Center; $\mu \mathrm{S} / \mathrm{cm}$, microsiemens per centimeter at $25^{\circ}$ Celsius; $\mathrm{ft}^{3} / \mathrm{s}$, cubic feet per second]

\begin{tabular}{|c|c|c|c|c|}
\hline Location & Date & $\begin{array}{c}\text { Specific } \\
\text { conductance } \\
(\mu \mathrm{S} / \mathrm{cm})\end{array}$ & $\begin{array}{c}\mathrm{pH} \\
\text { (units) }\end{array}$ & $\begin{array}{c}\text { Discharge } \\
\left(\mathrm{ft}^{3} / \mathrm{s}\right)\end{array}$ \\
\hline $\begin{array}{l}\text { Antelope Creek, N Street inlet to } \\
\text { tunnel- } \\
\text { 72-inch culvert downstream from }\end{array}$ & $5-9-83$ & 970 & $8 \cdot 0$ & 0.341 \\
\hline N Street- & do & 910 & 9.2 & trace \\
\hline $\begin{array}{l}\text { 23d and } O \text { Streets, } 48 \text {-inch tile } \\
\text { drain, west sidel- } \\
\text { 23d and } 0 \text { Streets, 26-inch square }\end{array}$ & do & 620 & $8 \cdot 0$ & .045 \\
\hline opening, east side-_- & do & 615 & 8.2 & $<.001$ \\
\hline P Street, 48-inch drain, west side- & do & 1,180 & 8.2 & $<.001$ \\
\hline $\begin{array}{l}\text { Q Street, 48-inch drain, east side- } \\
\text { Seep, } 22 d \text { Street between U and Vine }\end{array}$ & do & 615 & 8.2 & .015 \\
\hline $\begin{array}{l}\text { Streets, alley side of U Street }{ }^{1-} \\
20 \text { th and Vine Streets, } 60-\text { by } 40-\end{array}$ & do & 3,200 & 6.8 & $-\cdots$ \\
\hline $\begin{array}{l}\text { inch drain, west sidel } \\
\text { Antelope Creek southwest of Cushman- }\end{array}$ & do & 1,300 & 7.7 & $<.001$ \\
\hline $\begin{array}{l}\text { OMC Plant exit from tunnel } \\
\text { Weep hole } 30 \text { feet downstream from }\end{array}$ & do & 970 & 8.0 & .517 \\
\hline $\begin{array}{l}\text { tunnel, east side- } \\
\text { Seep, 2d panel downstream from } \\
\text { gabion section by Cushman-OMC }\end{array}$ & do & 2,120 & 6.6 & ---- \\
\hline Plant, west side- & do & 1,800 & 6.7 & ---- \\
\hline $\begin{array}{l}\text { Drain from Cushman-OMC Plant------ } \\
\text { 15-inch drain, } 100 \text { feet downstream } \\
\text { from Cushinan-OMC Plant by RR. }\end{array}$ & do & 610 & 8.2 & .08 \\
\hline $\begin{array}{l}\text { bridge, west side- } \\
\text { Drain at RR. bridge near Cushman- }\end{array}$ & do & 620 & 8.2 & .003 \\
\hline OMC Plant, west side & do & 1,725 & 7.1 & .02 \\
\hline $\begin{array}{l}\text { Drain at RR. bridge, east side----- } \\
\text { 66-inch drain at } Y \text { Street, down- }\end{array}$ & do & 620 & 8.2 & .03 \\
\hline $\begin{array}{l}\text { stream from gage, east side- } \\
\text { Outfall under loth Street overflow }\end{array}$ & do & 1,080 & 7.3 & $<.001$ \\
\hline $\begin{array}{l}\text { Tributary to Antelope Creek, north } \\
\text { end of RR. bridge, downstream }\end{array}$ & do & 2,000 & 8.0 & $<.001$ \\
\hline $\begin{array}{l}\text { from } 16 \text { th and Holdrege Streets--. } \\
\text { Seep, } 10 \text { feet downstream from first } \\
\text { RR. bridge upstream from Court }\end{array}$ & do & 1,070 & 7.7 & 2.005 \\
\hline Street site, west side- & do & 1,550 & 6.8 & \\
\hline
\end{tabular}


Table 4.--Specific-conductance survey of water from Antelope Creek main channel and from drains into Antelope Creek tunnel and seeps into cement-1ined channel, May 9, 10, 1983--Continued

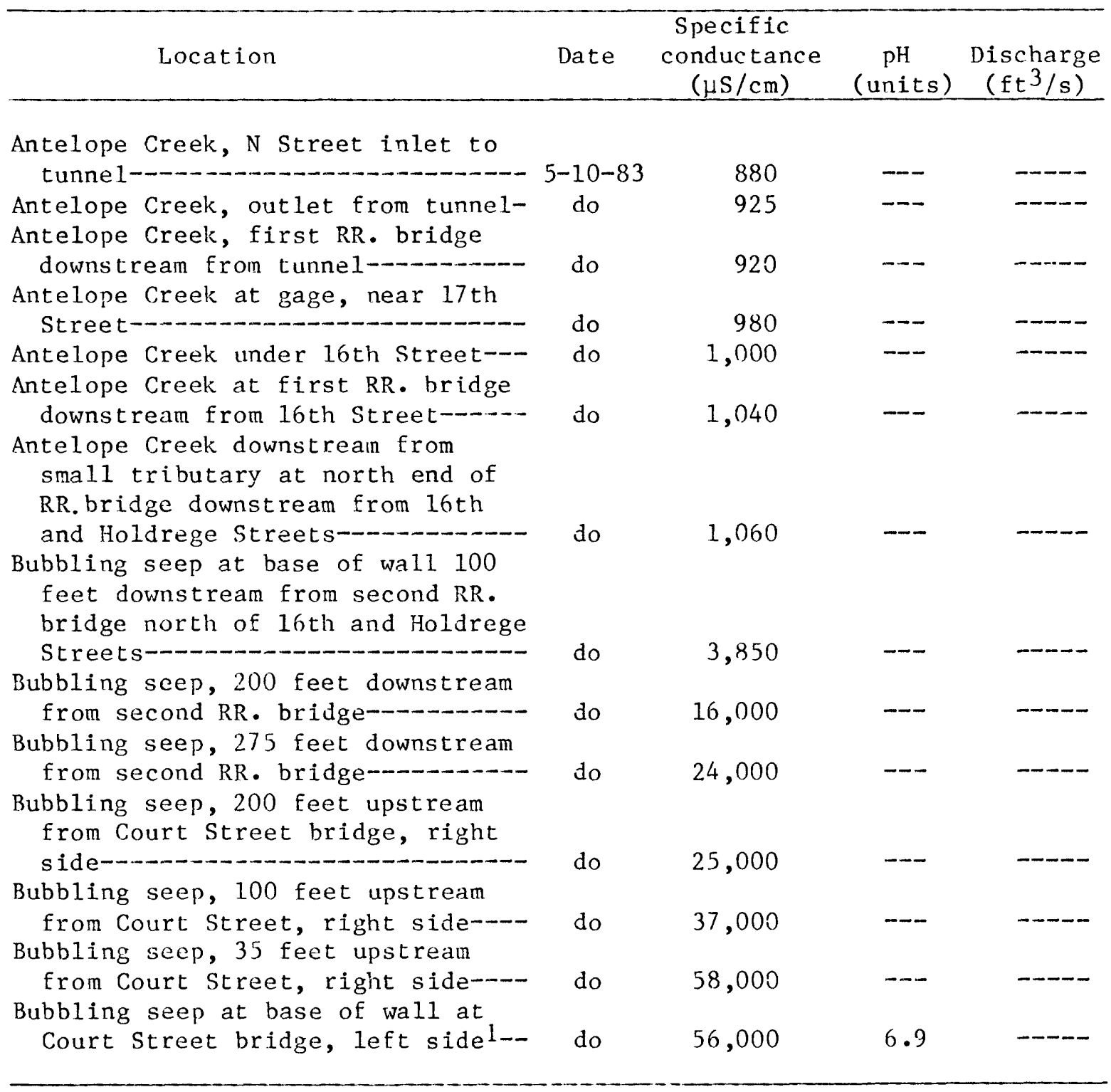

${ }^{1}$ Samples collected for chemical analyses.

2Estimated. 
Table 5.--Specific-conductance survey of Deadmans Run main channel from Wedgewood Lake outlet to U.S. Highway 6 bridge and principal tributaries or outfalls, Decenber 1,1982

$\left[\mu \mathrm{S} / \mathrm{cm}\right.$, microsiemens per centimeter at $25^{\circ}$ Celsius]

\begin{tabular}{|c|c|c|}
\hline Location & $\begin{array}{c}\text { Specific } \\
\text { conduct ance } \\
(\mu \mathrm{S} / \mathrm{cm})\end{array}$ & $\begin{array}{c}\mathrm{pH} \\
\text { (units) } \\
\end{array}$ \\
\hline Main channel at Wedgewood Lake outlet & 528 & 8.00 \\
\hline Drain from east at West Rio and Skyray Roads- & 1,260 & 8.00 \\
\hline $\begin{array}{l}\text { Main channel at } 70 \text { th street } \\
\text { Drain from south upstream from } 66 \text { th Street (East }\end{array}$ & 1,160 & 7.45 \\
\hline Park Plaza) & 1,170 & 7.90 \\
\hline Main channel at 66 th street- & 765 & 7.80 \\
\hline Drain downstream from 66th Street near McGinnis Ford & & \\
\hline Agency-- & 945 & 7.15 \\
\hline Main channel at Cotner Boulevard- & 813 & 7.85 \\
\hline Open drain No. 4- & 976 & 8.35 \\
\hline Open drain No. 3 & 647 & 7.90 \\
\hline Open drain No. 1 & 908 & 7.95 \\
\hline Main channel at 56th Street- & 866 & 8.45 \\
\hline Main channel at 52d street- & 816 & 8.35 \\
\hline Main channel at 48 th Street- & 785 & 8.35 \\
\hline Creek from south, downstream from $48 \mathrm{th}$ Street------- & 267 & 7.35 \\
\hline Main channel at 37 th Street- & 935 & 8.20 \\
\hline Main channel at 33d Street- & 936 & 8.10 \\
\hline Drain from south, upstream from U.S. Highway 6 & 305 & 7.60 \\
\hline Main channel at U.S. Highway S- & 1,120 & 7.85 \\
\hline
\end{tabular}

